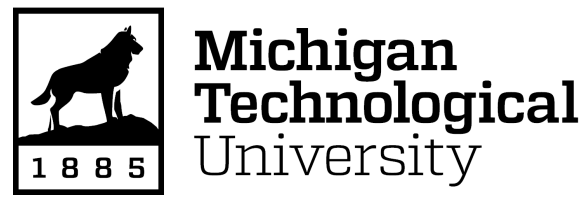

Michigan Technological University Digital Commons @ Michigan Tech

Dissertations, Master's Theses and Master's Reports

2020

\title{
AN INVESTIGATION OF THE IMPACT OF A STEM PROGRAM ON STUDENTS' KNOWLEDGE ON INTEREST IN STEM
}

Danielle Dean

Michigan Technological University, danierga@mtu.edu

Copyright 2020 Danielle Dean

\section{Recommended Citation}

Dean, Danielle, "AN INVESTIGATION OF THE IMPACT OF A STEM PROGRAM ON STUDENTS' KNOWLEDGE ON INTEREST IN STEM", Open Access Master's Report, Michigan Technological University, 2020.

https://doi.org/10.37099/mtu.dc.etdr/1043

Follow this and additional works at: https://digitalcommons.mtu.edu/etdr

Part of the Curriculum and Instruction Commons 


\title{
AN INVESTIGATION OF THE IMPACT OF A STEM PROGRAM ON STUDENTS' KNOWLEDGE ON INTEREST IN STEM
}

\section{By}

Danielle A. Dean

\begin{abstract}
A REPORT
Submitted in partial fulfillment of the requirements for the degree of MASTER OF SCIENCE

In Applied Science Education

MICHIGAN TECHNOLOGICAL UNIVERSITY

2020
\end{abstract}

(C) 2020 Danielle A. Dean 
This report has been approved in partial fulfillment of the requirements for the Degree of MASTER OF SCIENCE in Applied Science Education.

Department of Cognitive and Learning Sciences

\author{
Report Advisor: Kedmon Hungwe \\ Committee Member: $\quad$ Shari Stockero \\ Committee Member: John Irwin \\ Department Chair: Kelly Steelman
}




\section{Table of Contents}

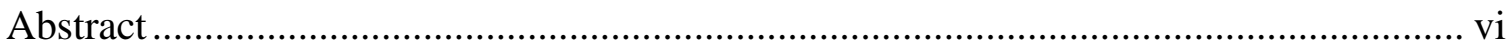

Chapter 1: Introduction, Context, and Research Objectives................................................1

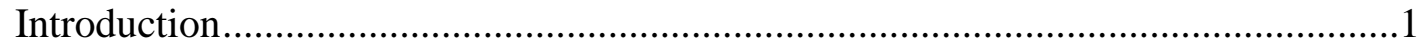

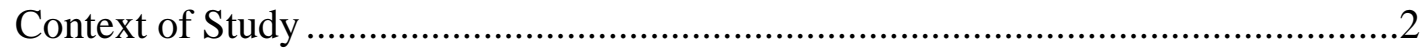

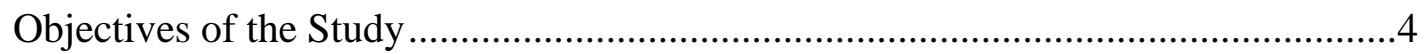

Research Questions ................................................................................

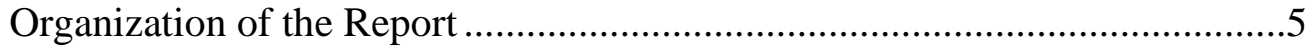

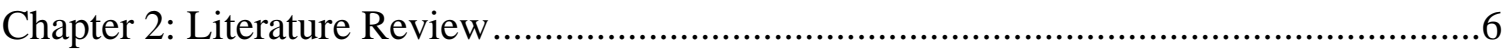

Summary and Discussion................................................................................

Chapter 3: Research Methodology and Design ............................................................11

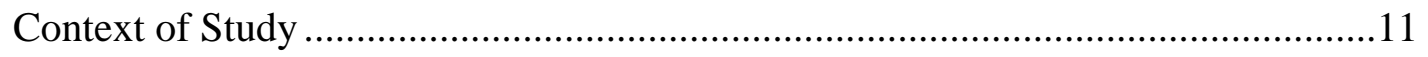

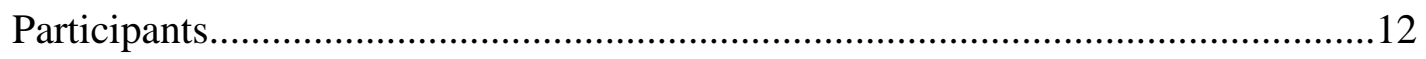

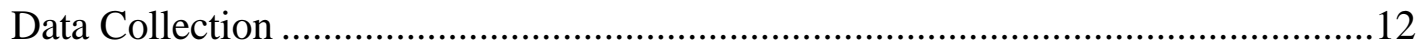

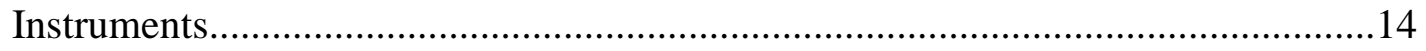

Ethics 15

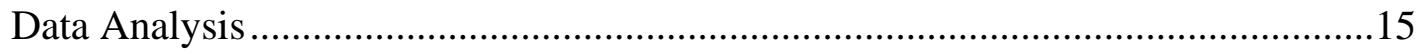

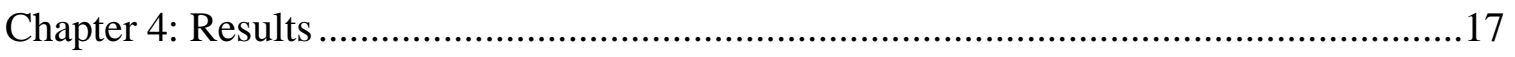

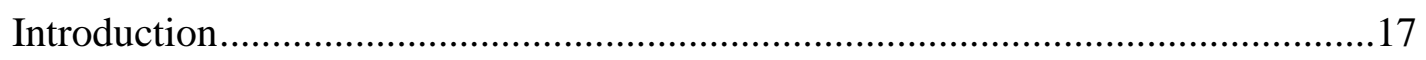

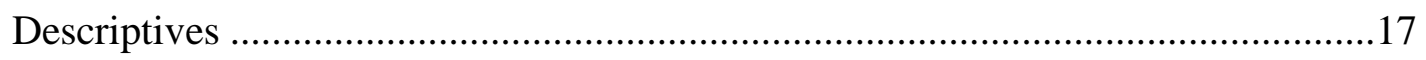

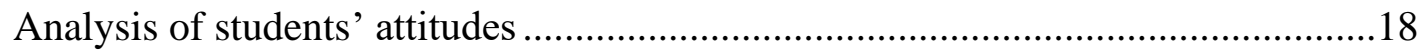

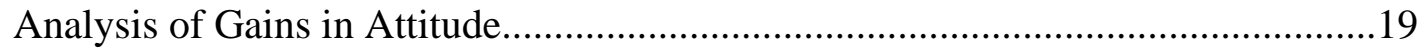

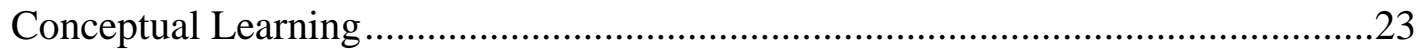

Comparative analysis of males and female on the rubric..............................28

Students Attitude to Online Learning .....................................................................29

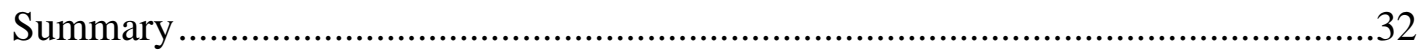

Chapter 5: Conclusions, Limitations, and Recommendations ...........................................33

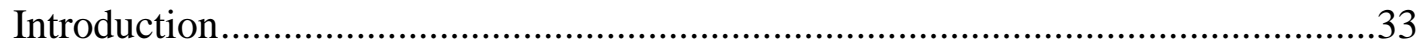

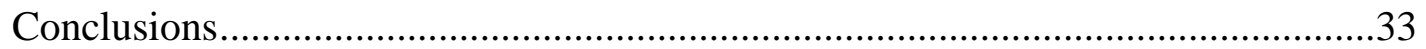

What is the effect on participants' attitudes toward science ...........................33

The effect on participants' knowledge of engineering standards .....................34 
The effect on participants' attitudes towards STEM careers..........................34

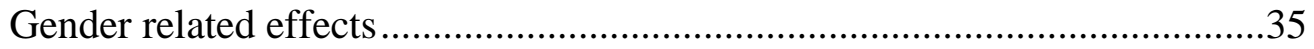

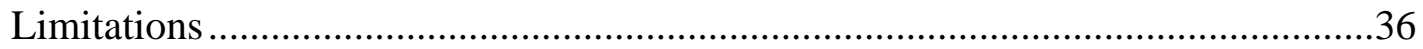

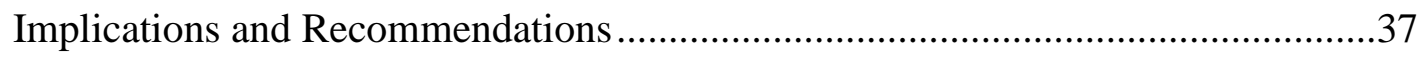

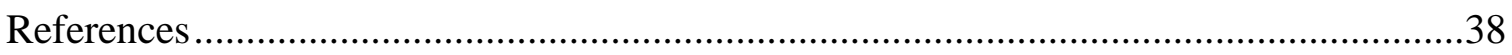

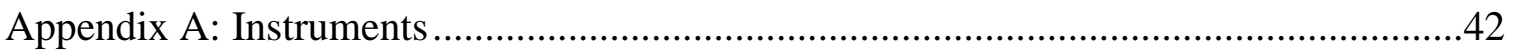

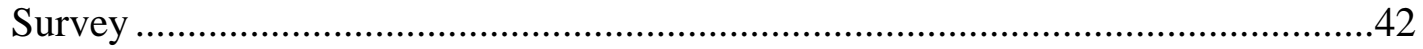

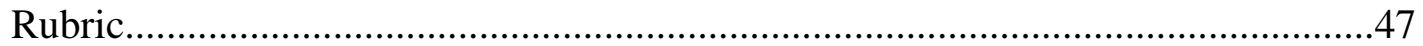

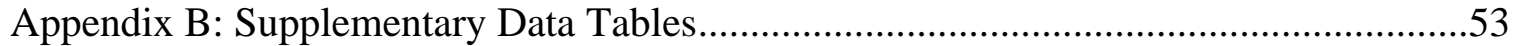

Table 15: Descriptive Statistics Rubric Scores.................................................53

Table 16: Independent Samples T-Test Rubric Scores ......................................54

Table 17: Descriptive Statistics Rubrics Males vs Females ............................55

Table 18: Independent Samples T-Test Rubric Males vs. Females ..................56

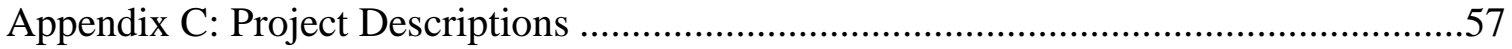

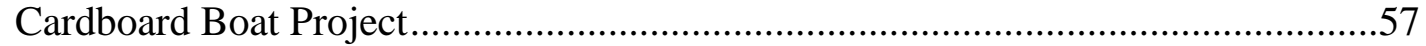

Miniature Crime Scene Project........................................................................57

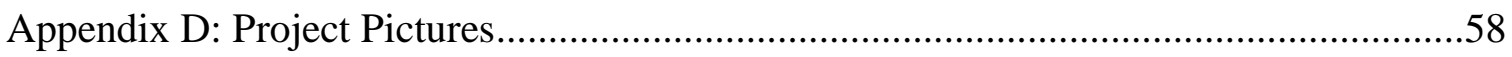




\title{
Acknowledgments
}

\author{
A special thanks to: \\ Graduate Committee Members, especially Dr. Kedmon Hungwe \\ Teachers and Administration at Western Middle School \\ My family especially my husband Eric \\ And to all that one way or another accompanied me through this journey.
}




\begin{abstract}
An Investigation of the Impact of a STEM Program on Students' Knowledge on Interest in STEM

By

Danielle A. Dean
\end{abstract}

The objective of the study was to investigate middle school students' attitudes towards Science, Technology, Engineering, and Math (STEM), as well as their knowledge about engineering practices. A quantitative design was employed with a total of 51 participants randomly assigned to two conditions. 24 students took a STEM elective course and the other 27 an equivalent course with a career focus on forensics as a career.

Over nine weeks participants took a pre and post survey on attitudes and completed a project that was assessed using a common rubric. The results on gains in student attitude were mixed. On the overall gains, the STEM course had no effect, while the forensics course had a negative gain $(\mathrm{p}<0.05)$. The supplementary survey conducted for online learning showed that students taking the forensic course were more affected by the shift to online learning than those taking the STEM option. The survey also showed that the math attitude items were significantly different $(\mathrm{p}=0.02)$. The results suggest that including more projects with a math component will increase students' attitudes towards math in STEM.

A rubric was used to assess knowledge of engineering practices in both the forensic and STEM courses. The results showed a significant difference in the category "Analyzing and Interpreting Data" ( $p=0.003)$. Looking at each engineering practice for both classes combined "Defining problems" and "Obtaining, Evaluating, and Communicating Information" were both significantly higher $(\mathrm{p}<0.001)$ than the test value.

The mean scores of males and females were compared between the classes. Females were significantly better at the practice of "Developing and Using Models" than males with $(\mathrm{p}=0.04)$. Males significantly thought that they learn just as well online as in the classroom compared to females who claimed they learn better in the classroom $(\mathrm{p}=0.041)$.

The overall findings should be considered as formative. The study contributes to an ongoing instructional improvement cycle for teacher leadership (Cherasaro et al, 2015; Achievement Network, 2020). 


\section{Chapter 1: Introduction, Context, and Research Objectives}

\section{Introduction}

Courses in science, technology, engineering and math (STEM) provide the opportunity for students to learn how to apply knowledge that they have learned to situations and problems that could occur in the real world (Bybee, 2013). The objective of the study was investigate middle school students' attitudes towards STEM, as well as their knowledge about STEM concepts before and after taking a STEM class. According to the U.S. Department of Education (2019) it is more important than ever that students are creative problem solvers, that they can use information given to them as evidence, and that they use that evidence to make informed decisions. Nevertheless "many students lose interest in science and mathematics at an early age, and thus make an early exit from the so-called 'STEM pipeline'” (Sanders 2009, p. 22). A STEM class designed around the engineering standards and having students solve problems like those they may face in the real world may lead some students into pursuing a degree or job in that field in the future (Teach, 2019). The engineering design process guides the students through the design and execution of projects. Students are able to learn about engineering and the skills that go with it, engineering skills are so economically important to our society (Bybee, 2010). Furthermore, STEM-related jobs have grown three times as fast as non-STEM related jobs over the past ten years (Smithsonian Science Education Center, 2019). Therefore, getting students interested in the STEM field is very important. 
Western Middle School decided that since STEM is so important that it would be beneficial to create an elective course. Teaching the STEM elective course is challenging due to the fact there is no curriculum or even standards to follow. The research project is based on specially created STEM course work that I created and implemented at Western Middle School in Auburn, Michigan. The curriculum was designed around project-based learning and the engineering standards taken from the Next Generation Science Standards.

Through teaching these STEM elective courses I wanted to make sure to address the stereotypes of males and females and their roles in STEM careers. Although women fill close to half of all jobs in the U.S. economy, they hold less than 25 percent of STEM jobs (Beede, Julian, Langdon, McKittrick, Khan, Beethika, \& Doms, 2011). I planned on changing students' attitudes and making them see that women are also capable of having STEM related careers.

Using project-based learning I planned to increase students' understanding of how things work in their daily lives and how to improve them through problem solving and incorporating technology, both critical elements of STEM education (Bybee, 2010). The intent was to create coursework that is hands on, with students working collaboratively using the engineering process to solve problems.

\section{Context of Study}

The study is based on a comparison of two curriculum innovations that I created at Western Middle School. In 2017 I created and implemented a nine-week elective STEM 
course. The course is project-based and uses the engineering practices. Students work on seven different projects that are unrelated. The projects are creation of a Rube Goldberg machine, creating a catapult and looking at forces, making tessellations and studying transformations, making a balloon car and studying the transfer of energy, creating an arcade game using the engineering design process, and designing and building a kite studying scale models

In 2019 I decided to develop a STEM elective course with a thematic focus on Forensic Science. Although I did not have evaluation on my first course, I believed that that a forensic course would be more effective in arousing student interest in STEM careers, and consequently also result in greater learning gains. Many students have negative stereotypes about engineers and scientists. I chose Forensic Science as a gateway to teach students important STEM concepts and the engineering design process. Students are very familiar with forensics, often seeing it on television and in the movies, but only have limited knowledge about all the science skills that go into it. By introducing students to careers such as DNA analyst, anthropologist, forensic technician, and forensic pathologist, I believed that students would begin to reverse stereotypes about STEM and see careers in STEM as something they could aspire toward.

The goal of the forensic course is to enable students to see science through the eyes of a crime scene investigator. By looking at problems through the eyes of a crime scene investigator. they will learn to collect and analyze evidence and other scientific strategies and skills. This course covers three main areas of science: Physical, Earth, and Life Science. There are nine one-week modules that students participate in: Deductive 
Reasoning, Crime Scene Sketching, Handwriting Analysis/Document Forgery, Fingerprint Analysis, Microscope Forensics, Forensic Anthropology, Blood Spatter Analysis, Trace Evidence, and Mock Crime Scenes.

\section{Objectives of the Study}

The study compared the Forensics class with a more typical STEM class. I sought to determine whether students took more interest and connected more to the curriculum when STEM was taught through the lens of forensics than in traditional STEM course. My focus was on the impact on STEM career interest and in knowledge.

Students' knowledge of engineering standards was assessed through coursework projects and using rubrics. STEM career interests were assessed using student surveys. There are eight engineering practices (NSTA, 2014) that we focused on: defining problems, developing and using models, planning and carrying out investigations, analyzing and interpreting data, using mathematics and computational thinking, constructing explanations and designing solutions, engaging in arguments from evidence, and obtaining, evaluating and communicating information.

\section{Research Questions}

The set of research questions compares the impact of two approaches to teaching STEM with respect to 1) interest in STEM careers, and 2) student knowledge of STEM concepts. The difference was that one course (the forensic course) was designed to focus on a real world, career application, while the other was based on tasks that were not tied to a 
STEM career. A supplementary question was added to assess students' views about online learning. This was included following the forced closure of the school as a result of the COVID-19 health emergency. The research questions are:

1. What are the comparative effects of two engineering practice-based courses on participants' attitudes toward science?

2. How do the male and female middle school students differ in their improvement in STEM content knowledge and perceptions after participating in the elective courses?

3. What are the effects of the switch to online learning as perceived by the students? Were there any differences in perception between the two course options and between males and females?

\section{Organization of the Report}

Chapter 2 presents the literature review. This is followed by a discussion of methodology and design in chapter 3 . The results are presented in chapter 4 . Finally, the conclusions and recommendations are presented in chapter 5. 


\section{Chapter 2: Literature Review}

STEM (science, technology, engineering, and math) careers are some of the most important careers in the present-day and future world (Hossain \& Robinson, 2012). Jobs in the STEM fields have made major contributions to society; those contributions make our lives easier and our world a better place (Hossain \& Robinson, 2012). Our world is becoming more reliant on technology, and we are becoming more reliant on the workers in this career field. There are concerns, however, about the future STEM workforce here in the United States. Thus, government officials, educators, and corporations have tried to bring attention to this issue and are promoting STEM education and STEM careers (Laforce, Noble, \& Blackwell, 2017). Here in the U.S. there are some initiatives to improve STEM education (Knezek et al., 2013). Middle school is a critical point to begin the preparation of students for STEM careers by nurturing their interest in science, technology, engineering, or math (Knezek, et al., 2013).

Motivation is just one component that seems to influence students' attitudes towards STEM and STEM careers. Many students who are capable academically lack motivation and leave the prospect of a future STEM career behind in high school or college (Hossain \& Robinson, 2012). It is important to figure out a way to reach these students and increase their interest in STEM. In order to build a stronger STEM workforce, we need to tap into students' interests and get them motivated (Laforce, Noble, \& Blackwell, 2017). In recent years the number of students who earned college degrees in engineering declined by almost 20\% in the US from 2000-2010 (Hossain \& Robinson, 2012). However, careers in the engineering field are expected to grow three 
times faster than all other fields combined. There are not enough engineering students currently to meet that demand (Gibbons, Hirsch, Kimmel, Rockland, and Bloom, 2004). According to a study by Besterfield-Sacre, Atman, and Shuman (1997) students who left engineering programs with grades similar to those that stayed in such programs had significantly poorer attitudes towards engineering. Research suggests that in order to get students motivated and inspired towards STEM, classes need to be more hands on and work on problem solving skills and collaboration (Hossain \& Robinson, 2012).

A study by Krishnamurthi, Ballard, and Noam (2014) looked at the effects of multiple after-school STEM programs. Factors that contributed to interest in STEM included a hands-on style of learning, and opportunities to explore and investigate in core subject areas and gain real life skills. Students also learned relevant career skills, such as working in teams and collaboration. Students in many of these after school STEM programs learned how important STEM is to society and how STEM is helping to solve many of society's problems. They also had an increase in awareness of careers in the STEM field.

Self-efficacy has been identified to play a major role in student performance. Students who perform better academically were found to be more likely to continue to pursue interest in STEM programs. In STEM education, self-efficacy can make a difference in a student's academic performance and can be an indicator of a student's academic motivation (Simmon, Aulls, Dedic, Hubbard, \& Hall, 2015). Teachers' feelings of self-efficacy also have been linked to an increase in student motivation and positive attitudes in class (Stohlmann, Moore, \& Roehrig, 2012). 
When looking at STEM education and STEM careers it is important to examine the role that gender may play. Science is the one area where women are significantly underrepresented at all levels in post-secondary education (Simmon, Aulls, Dedic, Hubbard, \& Hall, 2015). Knezek, Christensen \& Tyler-Wood (2013) argued that the difference in gender is more related to the student's perceptions of science careers than based on the student's ability. In fact, studies have shown that females that have low selfefficacy tend to have a lower interest for STEM subjects compared to males. They also feel less prepared to take the lead on projects in STEM (Simmon, Aulls, Dedic, Hubbard, \& Hall, 2015).

A study by Knezek, Christensen and Tyler-Wood (2013) looked at inquiry-based learning and project-based learning with the goal to make the learning experience more student-centered. They designed a course to make students question, think critically and solve authentic problems. The results showed that student perceptions of mathematics and STEM content were positively impacted by inquiry-based and project-based learning. This helps students to become motivated independent learners. Research has indicated that classroom factors, as well as differences in individual students, can significantly predict students' career aspirations. Creating positive experiences with mathematics can help influence students' perceptions about the mathematics involved in a STEM courses (Knezek, Rhonda, Christensen, Tyler-Wood, \& Periathiruvadi, 2013).

Stohlmann, Moore, \& Roehrig (2012) argue for integrated STEM education, and thus their goal is to combine STEM content into a class that is based on solving realworld problems and phenomena. Project Lead the Way (PLTW) is one such integrated STEM curriculum. The study performed by Stohlmann, Moore, and Roehig (2012) 
examined a middle school that had adopted PLTW as its STEM curriculum. The authors discovered that one large factor in determining if STEM education is effective was the teacher. In order to be effective, the teacher must be dedicated and knowledgeable in STEM content. Teachers that had the best results were those who wanted to teach STEM and were not looking to switch into teaching a different subject.

Research suggests that most STEM courses seem to focus around the engineering design process. A study by Judson, Ernzen, Krause, Middleton, \& Culbersont (2016) discussed how engineering standards are used in the middle school and how teachers interpret them. These authors collected information on how the Next Generation Science Standards were being interpreted and implemented in middle school science classrooms because, "Understanding how NGSS will be interpreted and implemented is extremely important in order to execute NGSS' Science and Engineering Practices (SEPs) and Disciplinary Core Ideas (DCIs) of Engineering Design effectively" (Judson, Ernzen, Krause, Middleton, \& Culberston, 2016). The study indicated that middle school science teachers are already skilled at having students analyze data, but where teachers indicated they need more help is in how to teach the engineering design process. Teachers indicated that the engineering standards were a point of weakness. Engineering standards are a point of focus in this project.

\section{Summary and Discussion}

From the literature, we have learned that STEM jobs are increasing in numbers, but the number of students going into STEM careers does not correlate. STEM is being promoted in schools and society but there is still a lack of interest in these careers. 
Motivating the students by making STEM content hands on, integrated, and project based, seems to make students attitudes towards STEM careers more positive. When looking through the literature I did not find much information on teaching STEM through a real-life career focus. Some STEM courses did focus on looking at many different STEM careers, but I did not find much that had students study STEM through one career like forensics. There seems to be a lack of information on classes designed around the engineering practices from NGSS. The information that I found talked about how the engineering design process is a point of weakness for teachers, so this is something that gets left out. By giving the class a focus and using the engineering practices as a guide I had hoped to pique students' interest in STEM. 


\section{Chapter 3: Research Methodology and Design}

In order to discover if students' attitudes and knowledge toward STEM are affected by an informal science enrichment class taught through the real-world application of forensics, I used a quantitative methodology and design with two whole class groups that were compared using statistical procedures. Data were collected through a survey and a course rubric (see appendices).

\section{Context of Study}

The research took place at Western Middle School in Auburn, Michigan. Auburn is a rural town; a majority of the population is middle class Caucasian. Western Middle School is grades sixth through eighth' and it is connected to our High School. There are six class periods in a day, four core classes and two elective classes. Students do not get to pick their electives; they are chosen at random. Most elective courses are nine weeks, with the exception of band and foreign language. The two elective classes that are the focus of this study are STEM and Forensics. In 2018 I developed the curriculum for the eighth grade STEM elective class based on the engineering design process. I found that students were starting to get bored of STEM if they had it in more than one grade level. For example, a student could have already had a STEM course and done similar problembased learning in sixth grade and then be assigned it again in eighth grade. For the 2019 school year I decided to take the concepts taught in STEM (engineering practices) and teach them in a new way. I wanted to pique students' interest again, so I designed a new eighth grade STEM course based on forensic science. The eighth grade STEM course is 
still an elective taught by a different teacher who is using the curriculum that I developed. In this study I am comparing the regular STEM course with my new Forensic STEM course to see if teaching STEM through a particular career lens would increase students' attitude and knowledge towards STEM careers.

\section{Participants}

The participants were minors (eighth grade students) at Western Middle School, Auburn, Michigan. The research took place in their elective STEM or Forensics class. Two classes taking two different versions of an elective class participated. The first class took a STEM elective course, and the second took a Forensics course elective. The students were randomly enrolled in the courses and did not have a choice in their elective class. The Forensic class was taught by me and the STEM class was taught by a different teacher. The class sizes were 27 students for the Forensics class ( 14 females and 13 males), and 24 students for the STEM course (14 females and 10 males).

\section{Data Collection}

Quantitative data were gathered using surveys and project scoring rubrics. All students took a survey at the beginning of the nine weeks and again at the end. There was a time gap of five weeks between week eight and week nine where no instruction was given due to the circumstances surrounding COVID-19. The survey was designed to help gain insight into the students' attitudes towards Science and STEM careers. The surveys used the Likert scale to measure students' attitudes (see Appendix A). To gather data on students understanding of the engineering standards I created a rubric using the 
NGSS engineering standards (see Appendix A). This rubric was used to grade students' projects that were completed as part of the course. This was a criterion-referenced informal assessment and provided quantitative data.

During the nine-week Forensic course, students participated in nine different modules: Deductive Reasoning, Crime Scene Sketching, Handwriting Analysis/Document Forgery, Fingerprint Analysis, Microscope Forensics, Forensic Anthropology, Blood Spatter Analysis, Trace Evidence, and Mock Crime Scenes. During each of these modules' students used project-based learning and applied the NGSS engineering standards. The activities in this course were structured to develop skills necessary for forensic engineering and to develop an understanding of what a forensic engineer does, and to get the students engaged and excited about the content. In the STEM course students had seven major projects throughout the nine weeks. They included designing a Rube Goldberg machine, building a catapult, building a cardboard boat, creating a tessellation, designing and testing a balloon car, building a kite, and making an arcade game. Each of these projects' required students to use the engineering design process. The projects were structured to develop problem solving skills, and to get the students engaged and motivated about engineering.

The data for the study were collected from a group project completed towards the end of the course. Students were groups of three to four students and assigned a project. In the forensic course, the groups were by gender with males and females in different groups. In the STEM class, the groups were mixed. This was not a planned difference. 
In the Forensics course students were assigned to create a model of a crime scene using evidence to prove a suspect was guilty. Students had to first write a description of the crime making sure to use at least three pieces of evidence, then sketch a blueprint of the crime scene including the scale factor and, from that blueprint create an actual model of the crime scene. Then they had to present their case to the "court" which was our class using their evidence to identify the suspect. In the STEM course students built cardboard boats. First students had to create a blueprint of their boat including the scale factor, find the density of the boat, then build the boat according to their blueprint using only materials provided. On test day students had to paddle their boat the length of the swimming pool, then create a Google Slide presentation describing their results and what they would change if they were to design their boat again.

\section{Instruments}

The Likert scale survey used was adapted from Friday Institute for Educational Innovation (Friday Institute for Educational Innovation, 2012). Some of the questions were left out of the original survey because they did not apply to the research. Additional questions were added to the post survey due to the online learning component after COVID-19. The first section of the survey focused on students' attitudes towards math. Examples of prompt questions were "math has been my worst subject" and students had to rate their agreement on a scale ranging from "strongly disagree" to "strongly agree." The next section on the survey was on students' attitudes towards science. Prompt items such as "I would consider a career in science" were used. Another section was on engineering and technology. The last section of the pre-survey was on STEM careers. 
This part of the survey gave students a STEM related career and its definition and students had to pick if they were not at all interested or very interested in that career. On the post survey the last section asked students to describe how they felt about online learning. Students were given a statement such as "I learn as well online as I do in the classroom" and then had to check whether they strongly disagreed up to strongly agreed. See the survey in Appendix A.

The rubric that was used to score projects was adapted from kidsengineer.com. The rubric uses the eight engineering practices as the categories and then describes exactly what students need to do for each practice. First it tells students the goal of that practice, and then describes how the student could perform poor, progressing, good, or advanced. In order to be successful students were looking at the "good" column (See the rubric in Appendix A). To keep results consistent between the two classes I scored the rubrics for both classes.

\section{Ethics}

No names or other identifying characteristics of any kind were used on the survey. The rubric used on the project did not collect student names. Each student participating in the project was assigned a number that identified any information associated with that student. The key that links student names to the coding has been kept in a locked cabinet.

\section{Data Analysis}

I looked at the results of the pre and post survey given at the beginning and the end

of the Forensic and STEM courses and entered all the results into an Excel file. I used the 
statistical package JASP to run descriptive statistics on the data. I also ran an independent groups t-test on the pre-surveys to see if there was a significant difference between classes in students' attitudes towards STEM prior to the nine-week course. After that I ran descriptive statistics on the difference between students' post survey and their pre-survey (amount gained.). An independent group t-test was used to compare the two classes using gains as the outcome variable and comparing class groups which were the independent variable. The goal was to see if there were significant differences in student gains in attitude between the two groups. I also ran the t-test comparisons on gains using gender as the independent variable.

After looking at the gain in attitude towards STEM, I next looked at the additional questions added to the post survey that focused on online learning. I ran descriptive statistics on all questions to find the mean and then ran an independent t-test using classes as the grouping variable. Then I looked at the same questions and ran another t-test using gender as a grouping variable. I wanted to see if gender would influence online learning.

In the last stage of the analysis, I wanted to establish if the students had attained an acceptable level of performance, based on the rubric. This is different from just comparing the groups. The rubric had a 4-point scale as indicated in the appendix. The four levels of performance were set at $1=$ poor $2=$ progressing, $3=$ good, and $4=$ advanced. For the statistical analysis I set level 3 (good) as the target for the class average. I could therefore run the data from the students to determine the average scores and also determine if the class averages were significantly different from the target average performance of 3.0 (good). I could also compare the performance by gender. 


\section{Chapter 4: Results}

\section{Introduction}

This chapter presents the results from the data analysis. The analysis focuses on the research questions as presented in chapter 1. They are:

1. What are the comparative effects of two engineering practice based courses on participants' attitudes toward science?

2. How do the male and female middle school students differ in their improvement in STEM content knowledge and perceptions after participating in the elective courses?

3. What are the effects of the switch to online learning as perceived by the students? Were there any differences in perception between the two course options and between males and females?

The first section of the analysis presents descriptive data from the sample.

\section{Descriptives}

I administered the Attitude Towards STEM survey to 51 students in eighth grade, 27 of those students were in the Forensic elective course and 24 of those students were in the STEM elective course. The demographics are indicated in table 1.

Table 1: Data Sample

\begin{tabular}{|c|c|c|c|}
\hline \multirow[b]{2}{*}{ Class (1=forensic, 2-STEM) } & \multicolumn{2}{|c|}{ Gender } & \multirow[b]{2}{*}{ Total } \\
\hline & Female & Male & \\
\hline$\overline{1}$ & 13 & 14 & 27 \\
\hline 2 & 14 & 10 & 24 \\
\hline Total & 27 & 24 & 51 \\
\hline
\end{tabular}




\section{Analysis of students' attitudes}

Students took the initial survey in class prior to beginning any of the coursework, and the post survey after the nine-week course. The school was shut down in the eighth week. Instruction continued online. The post survey was taken online. Using the data collected I ran descriptive analysis and independent sample t-tests to compare the Forensic course to the STEM course. The goal was to determine if the courses were equivalent with respect to the impact on students' attitudes towards STEM. I hypothesized that the forensic course would have a greater impact because of the focus on real world applications.

I ran a t-test on the pre-survey scores. For the Science section of the survey, students in the STEM course had a more positive attitude towards Science before the course even began compared to the students in the Forensic course $(\mathrm{p}=0.004)$ (see table 2). There was no significant difference between the survey results for Math and Engineering/Technology, or STEM Careers attitudes.

Table 2: Pre-survey t-test Forensics vs. STEM

\begin{tabular}{lllll}
\hline & $\mathbf{t}$ & df & $\mathbf{p}$ \\
\hline Math Score (Pre-test) & -0.439 & 49 & 0.663 \\
Science score (pretest) & -3.010 & 49 & 0.004 \\
Engineering/Technology (pretest) & 0.303 & 49 & 0.763 \\
STEM Careers (pretest) & -1.626 & 49 & 0.110 \\
\hline
\end{tabular}


Figure 4.1 Pretest Science Attitude

Senres
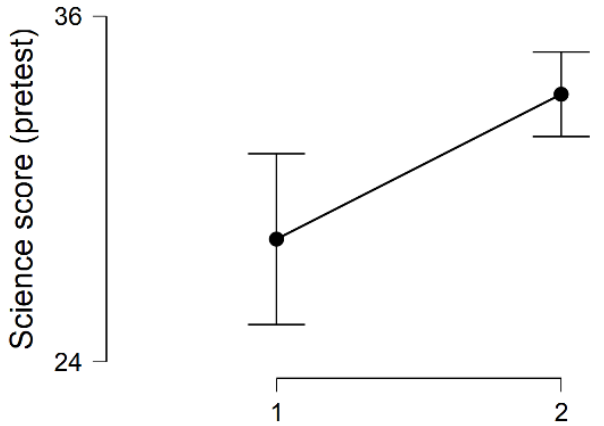

Class ( $1=$ forensic, 2 -STEM)

The descriptive data for the comparative analysis are presented in table 2 . The science pretest score mean was 28.26 for the forensic class, and 33.78 for the STEM course.

Table 3: Pre-test on Students Attitudes (Forensics =1 vs. STEM=2)

\begin{tabular}{lllllllll}
\hline & $\begin{array}{l}\text { Math Score } \\
\text { (Pre-test) }\end{array}$ & \multicolumn{2}{l}{$\begin{array}{l}\text { Science score } \\
\text { (pretest) }\end{array}$} & \multicolumn{2}{l}{$\begin{array}{l}\text { Engineering/Technology } \\
\text { (pretest) }\end{array}$} & \multicolumn{2}{l}{$\begin{array}{l}\text { STEM Careers } \\
\text { (pretest) }\end{array}$} \\
& $\mathbf{1}$ & $\mathbf{2}$ & $\mathbf{1}$ & $\mathbf{2}$ & $\mathbf{1}$ & $\mathbf{2}$ & $\mathbf{1}$ & $\mathbf{2}$ \\
\hline Valid & 27 & 24 & 27 & 24 & 27 & 24 & 27 & 24 \\
Missing & 0 & 0 & 0 & 0 & 0 & 0 & 0 & 0 \\
Mean & 24.481 & 25.042 & 28.259 & 33.292 & 33.778 & 33.250 & 28.074 & 30.833 \\
$\begin{array}{l}\text { Std. } \\
\text { Deviation }\end{array}$ & 5.727 & 2.645 & 7.497 & 3.483 & 5.886 & 6.543 & 6.805 & 5.062 \\
\hline
\end{tabular}

\section{Analysis of Gains in Attitude}

Next, I looked at the gain between a student's pre-survey score and their post survey score. In the first stage of the analysis, I combined the groups to see if the two treatments as a whole made a difference. I was looking to see if there was a statistically significant gain in students' attitudes in either course for any of the subject areas. The descriptive data are indicated below in table 4 . 
Table 4: Group Descriptives

\begin{tabular}{|c|c|c|c|c|c|}
\hline & Group & $\mathbf{N}$ & Mean & SD & SE \\
\hline \multirow[t]{2}{*}{ Gain (math) } & 1 & 27 & -0.074 & 3.474 & 0.669 \\
\hline & 2 & 24 & 2.542 & 4.293 & 0.876 \\
\hline \multirow[t]{2}{*}{ Gain (science) } & 1 & 27 & 0.074 & 4.514 & 0.869 \\
\hline & 2 & 24 & -0.042 & 3.507 & 0.716 \\
\hline \multirow[t]{2}{*}{ Gain (Eng Tech) } & 1 & 27 & -1.481 & 6.315 & 1.215 \\
\hline & 2 & 24 & 0.625 & 3.657 & 0.747 \\
\hline \multirow[t]{2}{*}{ STEM careers (Gain) } & 1 & 27 & -0.778 & 4.362 & 0.839 \\
\hline & 2 & 24 & -2.125 & 2.740 & 0.559 \\
\hline
\end{tabular}

The descriptive data show that student gains on the forensic option were negative on the career's questions (-2.125). The comparative data for the STEM course is marginally zero (that is no change). The difference between the groups was not statistically significant $(\mathrm{p}=0.199)$ (see table 5). The data trended in the negative direction for the forensic option with some strong negative outliers (see figure 4.2 below).

1

Figure 4.2 Forensic Knowledge Gain

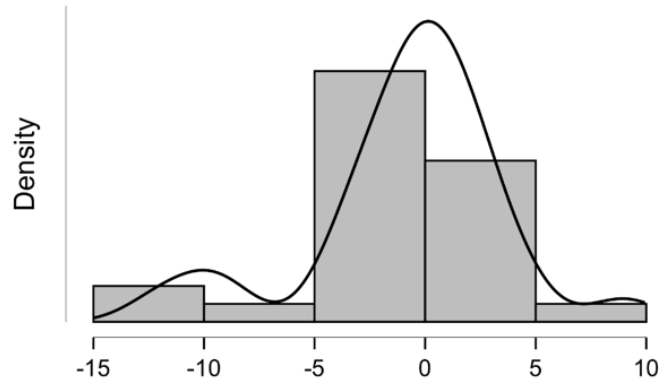

This was the opposite of what was expected. One explanation of the outcome is that the courses were moved online for the last segment. The data will show that students taking 
the forensic course were more affected by the shift to online learning more than those taking the STEM option. This is related to the type of projects that they completed for the courses.

Based on the table above, there appeared to be some differences between the means for the groups on the math gains. The mean gains were 0.07 for the forensic course (which is practically zero) and 2.54 for the STEM course. The other differences did appear to be significant. To check on the significance, I ran an independent t-test with my hypothesis stating that group 1 is not equal to group 2 (see table 5).

Table 5: Independent Samples t-test

\begin{tabular}{lrrr}
\hline & t & df & p \\
\hline Gain (math) & -2.403 & 49 & 0.020 \\
Gain (science) & 0.101 & 49 & 0.920 \\
Gain (Eng Tech) & -1.434 & 49 & 0.158 \\
STEM careers (Gain) & 1.301 & 49 & 0.199 \\
& & &
\end{tabular}

Note. Student's t-test.

The results indicate a significant difference in gain for attitudes towards math $(p=0.02)$. As noted, the Forensic course attitudes towards math scores stayed about the same, and the STEM course grew by a score of 2.5. Math was not explicitly taught in either course, but it was embedded within the projects. For example, in the Forensics course students had to create a sketch of their crime scene drawn to scale. This involved proportions, and computing lengths and areas. In the STEM course they had three projects throughout the nine weeks that had math components. One project was designing and building a cardboard boat. They had to create a blueprint of the boat and find the scale factor similar to the forensics scale drawing and they also had to calculate the 
density of the boat and compare it to the density of water to see if it would float. Another similar project was their kite project, where students had to design a blueprint of their kite and find the measurements, scale factor, area, and perimeter of their blueprint; in order to construct and fly their kite. The last project that included a math component was the tessellation project, this project allows students to demonstrate their knowledge of transformations, such as translations, rotations, and reflections. It seems that including more projects with a math component may have increased students attitudes towards math in STEM. With this information I think embedding math in projects is worth exploring more.

There was no statistical difference between the Forensics course and the STEM course when it came to the student's attitudes towards Science, Technology/Engineering, or STEM Careers. Other changes were not significant. There was a non-significant decrease in student's attitudes towards Math, Technology/Engineering and STEM careers after the Forensics course, and a decrease in students' attitudes towards science and STEM careers after the STEM course. Distractions may have skewed the results. Students only had eight weeks of face to face instruction in the classroom before the last week was done virtually due to COVID-19. As previously noted, there was a time gap of five weeks between week eight and week nine where no instruction was given due to the circumstances surrounding COVID-19. This time gap really could have affected students' attitudes and they may have not been completely focused when taking the post survey at home without teacher supervision. 
I also looked at gender to see if that played a role in the difference in attitude towards STEM. When I ran a t-test there was no statistically significant difference between the genders attitudes towards math, science, technology/engineering, or STEM careers (see Tables 6 and 7).

Table 6: Group Descriptives for Attitudes Males vs. Females

\begin{tabular}{|c|c|c|c|c|c|}
\hline & Group & $\mathbf{N}$ & Mean & SD & SE \\
\hline \multirow[t]{2}{*}{ Gain (math) } & Female & 27 & 1.519 & 4.449 & 0.856 \\
\hline & Male & 24 & 0.750 & 3.627 & 0.740 \\
\hline \multirow[t]{2}{*}{ Gain (science) } & Female & 27 & 0.222 & 3.965 & 0.763 \\
\hline & Male & 24 & $0.208^{-}$ & 4.180 & 0.853 \\
\hline \multirow[t]{2}{*}{ Gain (Eng Tech) } & Female & 27 & $1.296^{-}$ & 3.989 & 0.768 \\
\hline & Male & 24 & 0.417 & 6.426 & 1.312 \\
\hline \multirow[t]{2}{*}{ STEM careers (Gain) } & Female & 27 & 1.963 & 4.128 & 0.794 \\
\hline & Male & 24 & $0.792^{-}$ & 3.162 & 0.645 \\
\hline
\end{tabular}

Table 7: Independent Samples t-Test Males vs. Females

\begin{tabular}{lrrr}
\hline & t & df & p \\
\hline Gain (math) & 0.671 & 49 & 0.506 \\
Gain (science) & 0.377 & 49 & 0.708 \\
Gain (Eng Tech) & -1.158 & 49 & 0.253 \\
STEM careers (Gain) & -1.127 & 49 & 0.265 \\
& & & \\
\hline
\end{tabular}

Note. Student's t-test.

\section{Conceptual Learning}

The next set of results focuses on student knowledge as assessed by the project rubric. The rubric assessed knowledge of engineering practices in both the Forensic and STEM courses. 
The results showed a significant difference in the category "Analyzing and Interpreting Data" $(\mathrm{p}=0.003)$. The STEM class had a mean score of 3.125 and the Forensic class had a mean score of 2.444. It seems that the students in the STEM class were able to show their understanding of analyzing data better than the students in the Forensics class.

Table 8: t-test on Rubric Scores

\begin{tabular}{|c|c|c|c|}
\hline & $\mathbf{t}$ & df & $\mathbf{p}$ \\
\hline Rubric- Defining problems & 0.836 & 49 & 0.407 \\
\hline Rubric-Developing and using models & -0.232 & 49 & 0.817 \\
\hline Rubric-Planning and carrying out investigations & -0.046 & 49 & 0.964 \\
\hline Rubric-Analyzing and interpreting data & -3.138 & 49 & 0.003 \\
\hline Rubric-Using mathematics and computational thinking & -1.013 & 49 & $0.316^{\mathrm{a}}$ \\
\hline Rubric-Designing solutions & 1.364 & 49 & $0.179^{\mathrm{a}}$ \\
\hline Rubric-Engaging in argument from evidence & -1.706 & 49 & 0.094 \\
\hline Rubric-Obtaining, evaluating, and communicating information & -0.288 & 49 & 0.775 \\
\hline
\end{tabular}

I think the cardboard boat project (see chapter 3 and the appendix) allowed the students to show mastery of this concept easier than the Forensics project. Students had to calculate the boat's density and using that data decide if their boat would sink or float. This was easy to see when scoring the projects. In the Forensics class students had to use the three pieces of evidence and create a story that would implicate a suspect using that evidence. Students needed to show how all three pieces of evidence related back to the 
suspect and this was sometimes left out on students' projects which made this category harder to score.

In the next stage of the analysis, I sought to establish how well the students had performed on the rubric criteria based on the 4-point rating scale. A score of 3 (good/acceptable) was set as the target performance. I therefore used 3 as the test-value for a one sample t-test where the data from the two groups were aggregated and tested against the test-value. Aggregating the data was justifiable because when the t-tests were run with the test-value set at 3 there was no difference between the two groups. There were two criteria for which significant differences were found. The mean score for "Defining problems" was 3.49 which was significantly higher than the target 3.0 (p $<0.001$ ). The distribution of the data is shown in the bar graph (Figure 4.3) and it is skewed toward the higher level. Clearly students were good at figuring out the problem that needed to be solved.

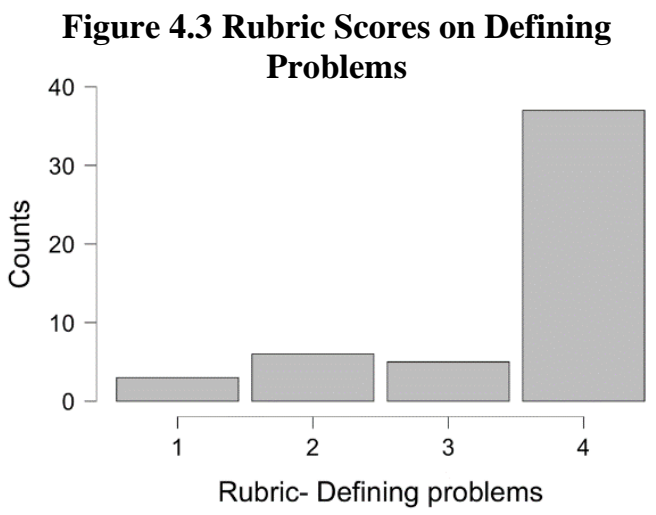

The data also showed a significant difference between the mean and target scores for the category "Obtaining, Evaluating, and Communicating Information" ( $p<0.001)$. 
The mean score was 3.725 . Students were very good at communicating their results as shown in the bar graph (Figure 4.4)

Figure 4.4 Rubric Scores on Communicating and Evaluating Information.

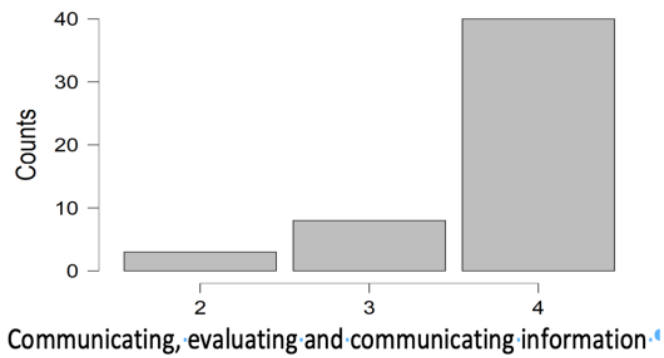

In the Forensic class students presented their models to the class and made an argument based around their evidence. In the STEM class students created a Google Slide presentation discussing their results and what they would do differently next time. This engineering practice seems to be covered well in both courses.

The mean scores for the following fell below 3.0, but the differences were not statistically significant: Analyzing and Interpreting Data $(M=2.77)$, Using Mathematics and Computational Thinking (2.37), Designing Solutions (2.69). See Table 10 below for the p-values. 
Table 9: Descriptives One Sample Rubric Scores

\begin{tabular}{lcccc}
\hline & N & Mean & SD & SE \\
\hline Planning and carrying out investigations & 51 & 3.118 & 1.070 & 0.150 \\
Defining problems & 51 & 3.490 & 0.925 & 0.129 \\
Developing and using models & 51 & 3.216 & 0.986 & 0.138 \\
Analyzing and interpreting data & 51 & 2.765 & 0.839 & 0.117 \\
Using mathematics and computational thinking & 51 & 2.373 & 0.848 & 0.119 \\
Designing solutions & 51 & 2.686 & 0.927 & 0.130 \\
Engaging in argument from evidence & 51 & 3.039 & 0.848 & 0.119 \\
Obtaining, evaluating, and communicating information & 51 & 3.725 & 0.568 & 0.080 \\
& & & &
\end{tabular}

\begin{tabular}{lccc}
\hline Table 10: One Sample T-Test Rubric Scores & & & \\
\hline \multicolumn{1}{l}{ Planning and carrying out investigations } & df & p \\
Defining problems & 0.785 & 50 & 0.218 \\
Developing and using models & 3.786 & 50 & $<.001$ \\
Analyzing and interpreting data & 1.562 & 50 & 0.062 \\
Using mathematics and computational thinking & -2.003 & 50 & 0.975 \\
Designing solutions & -5.287 & 50 & 1.000 \\
Engaging in argument from evidence & -2.416 & 50 & 0.990 \\
Obtaining, evaluating, and communicating information & 0.330 & 50 & 0.371 \\
\hline
\end{tabular}

Note. For the Student t-test, the alternative hypothesis specifies that the mean is greater than 3 .

Overall, the data indicate room for improvement in both the STEM forensic

courses. In the case of "Using Mathematics and computational thinking" the distribution of the scores had a modal value of 3 but was skewed towards the lower values as indicated below.

Figure 4.5 Rubric Scores on Using Mathematics and Computational Thinking

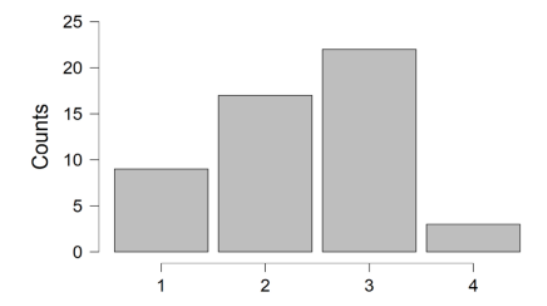

Using Mathematics and computational thinking." 
Students had a difficult time showing their thinking, especially in math. I had many students just write down the answer and not show their work. There were some groups that skipped the math portion of the projects all together, and there were many more groups who did not do the math correctly. When designing these classes again this is a engineering practice that needs to be addressed more often. Similar analysis needs to be done for the other practices on an ongoing basis using formative assessment.

\section{Comparative analysis of males and female on the rubric}

The mean scores of males and females were compared by class. The mean for females in the forensic class was 27.0. It was 21.21 for males. The difference is 5.786 and is statistically significant $(\mathrm{p}=0.013)$. The difference between males and females in the STEM course is 2.10 . It is not statistically significant. From this data it seems that the females in the forensic class gained a better understanding of the engineering practices than the males did.

Table 11 Rubric Scores Males vs Females

\begin{tabular}{|c|c|c|c|c|}
\hline Class (1=forensic, 2-STEM) & Gender & Mean & SD & $\mathbf{N}$ \\
\hline \multirow[t]{2}{*}{1} & Female & 27.00 & 1.225 & 13 \\
\hline & Male & 21.21 & 7.728 & 14 \\
\hline \multirow[t]{2}{*}{2} & Female & 24.00 & 7.656 & 14 \\
\hline & Male & 26.10 & 4.701 & 10 \\
\hline
\end{tabular}


As noted in chapter 3 males and females were in separate groups for the project in the forensic course, and they were mixed in the STEM course. The differences need further exploration. It is not clear to what extent the grouping had an effect on the outcome, in addition to the effect of instruction.

Another interesting point that came out of the data was comparing the rubric scores on specific engineering practices between males and females. The data shows that females were significantly better at the practice of "Developing and Using Models" than males with a $\mathrm{p}$ value of 0.04 . Females had an average score of 3.481 on the rubric where males had an average score of 2.917. I think eighth grade females tend to make their thoughts clearer and take their time making their model "look nice," and tend to have better organizational skills. Eighth grade male students have a tendency to just get their thoughts down without taking the time to make sure that their thoughts would be clear to others. The data tables are in Appendix B.

\section{Students Attitude to Online Learning}

As previously noted the last phase of the teaching was conducted online. It is reasonable to expect that these changes affected outcomes. The study therefore included questions on online learning which were added to the post-survey (see the Appendix A for the full set of questions). My goal was to investigate if there were differential effects of online instruction for the two courses. I also looked at differences between males and females with respect to online learning. When looking at the post survey and the added questions about online learning there was a significant difference $(p=0.041)$ between the 
Forensics class and STEM class on the statement "I learn as well online as I do in the classroom." More students in the STEM class responded that they learned just as well online as in the classroom with a class mean of 2.708, compared to the Forensics class which had a mean of 2.0. More students in the STEM class claimed it was easy to stay focused with online learning compared to the Forensics class $(\mathrm{p}=0.013)$. This may be due to the kind of activities that were assigned during the online learning portion or it could be just the group of students. In the Forensics class students had to choose a forensic science career and create a Google Slide presentation describing that career. They were also assigned to watch episodes of Forensic Files and write written responses to questions related to the episode and what we had previously learned in class. Students also had to study what it takes to become a forensic scientist by completing a CSI web adventure which is based off the CSI television show. Looking at these results I think more research can be done to see what activities, or strategies were used by the STEM teacher during the online learning phase that made the students more apt to say they prefer online learning and that they can stay focused while learning online.

Table 12: Descriptive Statistics for Online Learning Forensics vs STEM

\begin{tabular}{|c|c|c|c|}
\hline \multicolumn{2}{|c|}{$\begin{array}{l}\text { Online Learning [I learn as well online as } \\
\text { I do in the classroom.] }\end{array}$} & \multicolumn{2}{|c|}{$\begin{array}{l}\text { Online Learning [I find it easy to stay } \\
\text { focused with online learning.] }\end{array}$} \\
\hline 1 & 2 & 1 & 2 \\
\hline 27 & 24 & 27 & 24 \\
\hline 0 & 0 & 0 & 0 \\
\hline 2.000 & 2.708 & 2.074 & 2.875 \\
\hline 1.301 & 1.083 & 1.174 & 1.035 \\
\hline
\end{tabular}


Table 13: Independent Samples t-Test Forensics vs. STEM

\begin{tabular}{lrrc}
\hline & $\mathbf{t}$ & $\mathbf{d f}$ & $\mathbf{p}$ \\
\hline I learn as well online as I do in the classroom. & -2.098 & 49 & 0.041 \\
I find it easy to stay focused with online learning. & -2.570 & 49 & 0.013 \\
I need more interaction with other students during my online learning. & -0.715 & 49 & 0.478 \\
I need more interaction with the teacher with online learning. & 0.014 & 49 & 0.989 \\
I have all the materials needed to make online learning successful. & -1.140 & 49 & 0.260 \\
I have good access to internet for online learning. & -1.699 & 49 & 0.096
\end{tabular}

Looking at my second question related to online learning it seems that males seemed to think they learn just as well online as in the classroom compared to females who claimed they learn better in the classroom. With a $\mathrm{p}$ value of 0.041 there was a significant difference between males and females. More research could be done with this topic to see what the males found more appealing about online instruction.

Table 14: Group Descriptives Online Learning Males vs Females

\begin{tabular}{|c|c|c|c|c|c|}
\hline & Group & $\mathbf{N}$ & Mean & SD & $\mathbf{S E}$ \\
\hline \multirow[t]{2}{*}{ I learn as well online as I do in the classroom. } & Female & 27 & 2.000 & 1.074 & 0.207 \\
\hline & Male & 24 & 2.708 & 1.334 & 0.272 \\
\hline \multirow[t]{2}{*}{ I find it easy to stay focused with online learning. } & Female & 27 & 2.222 & 1.050 & 0.202 \\
\hline & Male & 24 & 2.708 & 1.268 & 0.259 \\
\hline \multirow{2}{*}{$\begin{array}{l}\text { I need more interaction with other students during my online } \\
\text { learning. }\end{array}$} & Female & 27 & 3.630 & 1.334 & 0.257 \\
\hline & Male & 24 & 3.417 & 1.248 & 0.255 \\
\hline \multirow[t]{2}{*}{ I need more interaction with the teacher with online learning. } & Female & 27 & 3.259 & 1.163 & 0.224 \\
\hline & Male & 24 & 3.333 & 1.167 & 0.238 \\
\hline \multirow[t]{2}{*}{ I have all the materials needed to make online learning successful. } & Female & 27 & 3.556 & 1.219 & 0.235 \\
\hline & Male & 24 & 3.917 & 1.018 & 0.208 \\
\hline \multirow[t]{2}{*}{ I have good access to internet for online learning. } & Female & 27 & 4.407 & 0.931 & 0.179 \\
\hline & Male & 24 & 4.125 & 1.227 & 0.250 \\
\hline
\end{tabular}


Table 15: Online Learning t-Test Males vs Females

\begin{tabular}{lcr}
\hline & $\mathbf{t}$ & $\mathbf{p}$ \\
\hline I learn as well online as I do in the classroom. & -2.098 & 0.04 \\
I find it easy to stay focused with online learning. & -1.497 & 0.14 \\
I need more interaction with other students during my online learning. & 0.586 & 0.56 \\
I need more interaction with the teacher with online learning. & -0.227 & 0.82 \\
I have all the materials needed to make online learning successful. & -1.140 & 0.26 \\
I have good access to internet for online learning. & 0.932 & 0.35 \\
\hline
\end{tabular}

\section{Summary}

There was a significant difference between the two courses when it came to students' attitudes towards STEM careers. The forensic class had a negative gain value while the STEM class had no change (i.e. a practically zero). The STEM class also showed a significant gain in attitude towards math compared to the Forensic class. There was no significant difference for students' attitudes in science, or technology/engineering for either class. The added questions about online learning showed a significant difference in that students in STEM thought they learned just as well online as in the classroom, and that staying focused with online instruction was easy compared to students in the forensic class. Using the rubric, I found that the STEM class scored significantly better at analyzing data than the forensic class. Both classes scored significantly higher than the "good" rating in the defining problems category and the obtaining, evaluating, and communicating information category. The results leave room for further investigation to better understand the factors that contribute the most to learning. More discussion of the findings follows in chapter 5. 


\section{Chapter 5: Conclusions, Limitations, and Recommendations}

\section{Introduction}

This chapter presents the conclusions, limitations, and recommendations. The conclusion focuses on the research questions as presented in chapter 1 . The discussion of the findings for each of the focus areas of the study follows.

\section{Conclusions}

\section{What is the effect on participants' attitudes toward science}

According to my results there is no evidence to say that students' attitudes toward science were positively affected by teaching STEM through the lens of Forensics. There was no significant gain shown in the results from the survey in either of the two classes. Once again this could be due to the distractions from COVID-19 and the fact that there were many variables that could not be controlled. For example, does the teacher matter? The fact that we were teaching similar content two different ways may not matter as much as our teaching styles may be different and that may impact students' attitudes more than the content we are teaching. Teachers have an influence on students based on their ability to establish expectations, use effective classroom management, and adapt curriculum materials for their students (Brophy, 1986). I think more research needs to be done with more variables controlled to get the clear results). I think further research can be done on embedding math into STEM projects. The one thing that was noted in the data was the increase in attitude towards math in the STEM course. This could be due to the fact that more of the projects in STEM had math embedded into them. According to the 
literature students that use math in their STEM courses could increase the appeal of computational thinking (Jona, et al, 2015). This is a topic that I would like to research more to see if including more math in the projects would make a significant difference in not only students' attitudes but in their assessment scores as well.

\section{The effect on participants' knowledge of engineering standards}

Looking at the results from both classes it looks like we are doing a great job teaching students' how to define a problem, and how to obtain, evaluate, and communicate information. Both standards had scores significantly higher than "good" on the rubric. The engineering standard we need to work on is mathematics and computational thinking. I think this is because both courses focus more on the science content than the math. Embedding more math in STEM will allow students to explore different mathematical approaches within the STEM context. Students will be seeing math skills being applied across the STEM curriculum and therefore STEM can enrich the process of learning mathematics (Jona et al., 2015). Having students practice computational skills in the STEM classroom will give them more of a realistic view of future careers. This will better prepare the students for what is expected in these fields (Jona, et al, 2015). I think further research can be done on embedding math into STEM projects.

\section{The effect on participants' attitudes towards STEM careers}

There was no significant effect of a STEM course or a Forensics course on students' attitudes towards a STEM career. This result surprised me. In the Forensics 
class students did a project where students had to explore a career in Forensic science and then present it to the class. I thought this might cause a few students to gain interest in a career in the STEM field. Making sure students have good information on STEM careers should make them more knowledgeable about possible career paths (Wyss, Heulskamp, \& Siebert, 2012). Being knowledgeable about a career may not make them interested in that career, however; that may come down to personal preference. At the middle level students need to feel inspired in STEM subjects (Hossain, \& Robinson, 2012). I do think exposing them to more career options is the best way to pique their interest.

\section{Gender related effects}

There was no significant difference between male and female students on their gain in attitude towards STEM. To change students' attitudes toward STEM and STEM careers we need to address stereotypical images, we need to show students what scientists and engineers really do. This needs to start from an early age (Eccles, 2012). This statement makes me think that trying to change middle school students' attitude in nine weeks may not be the best approach, it might need to start in kindergarten. One difference I did note was that female students scored significantly higher on the engineering practices rubric in the category developing and using models. I have a feeling this was due to the female students taking more time and making their models neater and more complete. 


\section{Limitations}

There were many limitations in this study that could have affected the gathered data. There were too many variables that could affect students' attitude towards STEM careers. One variable was the fact that it was two different teachers teaching the courses. Students interest in STEM may be piqued due to the way the teacher presented the material. This will vary from teacher to teacher and this could influence students' attitudes. The survey given did not have forensics as a specific career option for students to choose. The career categories were very broad, and students might not know which career goes in what category. Another variable was the students were placed into groups for the project that was graded with the rubric. This means that most students received the same score as the rest of their group even if they might not have mastered all of the same content. COVID-19 shut down the schools at week eight of this study, and all data was gathered before week eight with exception of the post survey. This survey was given online once school resumed five weeks later online. This delay in giving the post survey could have affected students' attitudes towards STEM. Also teaching online could have affected students' opinions as well. The data on online learning may also not be accurate due to the short time frame of online learning before the survey was given.

The study can also be improved by collecting qualitative data including interviews with students. This will provide more in-depth information about what has worked well and where changes can be made. 


\section{Implications and Recommendations}

The experimental study sought to compare two alternative approaches to teaching an elective STEM course, both designed by the same teacher. I had hypothesized that the forensic option would have a stronger impact overall because of the focus on real world applications. The results from the study were mixed. From this study I have determined that teaching STEM through a real-world lens such as forensics did not necessarily lead to better outcomes. There were other factors at play. These may include the tasks that were assigned. There were no significant gains in attitudes towards science, technology, or STEM careers and only a slight gain in math. Students in both classes did gain an understanding of some of the engineering practices as shown by the data gathered from the rubrics. These results should be considered as formative.

Although the uses of real-world application yielded mixed results I will recommend that Western Middle School retain it for further investigations. There were indications that students enjoyed it and it was for the most part just as effective as the STEM class in affecting students' attitudes towards STEM and teaching them the engineering practices. Other researchers can also contribute to this work by studying ways of designing tasks for real world applications that engage students and increase their interest in STEM careers. 


\section{References}

Besterfield-Sacre, M. J., Atman, C. J., \& Shuman, L. (1997). Characteristics of freshman engineering students: Models for determining student attrition in engineering. Journal of Engineering Education, 86(2), 139-149. doi: 10.1002/j.2168-9830.1997.tb00277.x

Achievement Network (2020). School leaders

https://www.achievementnetwork.org/school-leaders

Brophy, J. (1986). Teacher influences on student achievement. [Abstract]. American Psychologist, 41(10), 1069-1077. doi:10.1037/0003-066x.41.10.1069

Bybee, R. W. (2013). The case for STEM education: Challenges and opportunities. Arlington, VA: National Science Teachers Association.

Eccles, J. S. (2012). Gender and STEM: Opting In Versus Dropping Out. International Journal of Gender, Science, and Technology. Retrieved July 12, 2020, from http://genderandset.open.ac.uk/index.php/genderandset/article/view/315/529

Friday Institute for Educational Innovation (2012). Student Attitudes toward STEM Survey - Middle and High School Students, Raleigh, NC: Author.

Gibbons, S. J., Hirsch, L. S., Kimmel , H., Rockland, R., \& Bloom , J. (2004). Middle school students' attitudes to and knowledge about engineering. International Conference on Engineering Education. Retrieved from 
http://www.ineer.org/Events/ICEE2004/Proceedings/Papers/105_ICEE2004_Middle_Sch ool_Attitudes_(1).pdf

Hossain, M., \& Robinson, M. G. (2012). How to motivate US students to pursue STEM careers . US-China Education Review , A(12), 442-451.

Jona, K., Wilensky, U., Trouille, L., Horn, M., Orton, K., Weintrop, D., \& Beheshti, E. (2015). Embedding Computational Thinking in Science, Technology, Engineering, and Math (CT-STEM). Journal of Science Education and Technology, 127-147. Retrieved July 12, 2020, from http://ccl.sesp.northwestern.edu/papers/2014/OrtonKaiNorthwestern1.pdf

Judson, E., Ernzen, J., Krause, S., Middleton, J. A., \& Culbertson, R. J. (2016). How Engineering Standards are Interpreted and Translated for Middle School. Journal of PreCollege Engineering Education Research (J-PEER), 6(1). doi: 10.7771/2157-9288.1121

Kennedy, T. J., \& Odell , M. R. L. (2014). Engaging students in STEM education. Science Education International , 25(3), 246-258. Retrieved from https://files.eric.ed.gov/fulltext/EJ1044508.pdf

Knezek, G., Rhonda Christensen, R., Tyler-Wood, T., \& Periathiruvadi, S. (2013). Impact of environmental power monitoring activities on middle school student perceptions of STEM. Science Education International, 25(1), 98-123. 
Krishnamurthi, A., Ballard, M., \& Noam, G. G. (2014). Examining the impact of After School STEM Programs. Noyce Foundation .

Laforce, M., Noble, E., \& Blackwell, C. (2017). Problem-based learning (PBL) and student interest in STEM careers: the roles of motivation and ability beliefs. Education Sciences, 7(4), 92. doi: 10.3390/educsci7040092

NGSS Lead States. 2013. Next Generation Science Standards: For States, By States. Washington, DC: The National Academies Press.

Nsta. (2014). Science and Engineering Practices. Retrieved August 05, 2020, from https://ngss.nsta.org/PracticesFull.aspx

Sanders, M. (2009). STEM, STEM Education, STEMmania. The Technology Teacher, 2026. Retrieved from https://vtechworks.lib.vt.edu/bitstream/handle/10919/51616/STEMmania.pdf?sequence= $\underline{1 \& \text { isAllowed }=\mathrm{y}}$

Simmon, R. A., Aulls, M. W., Dedic, H. undefined, Hubbard, K. undefined, \& Hall, N. undefined. (2015). Exploring student persistence in STEM programs: A motivational model . Canadian Journal of Education, 38(1).

Smithsonian Science Education Center (2016) The STEM Imperative. Retrieved October 28, 2019, from https://ssec.si.edu/stem-imperative. 
Stohlmann, M., Moore, T., \& Roehrig, G. (2012). Considerations for teaching integrated STEM education. Journal of Pre-College Engineering Education Research, 2(1), 28-34. doi: $10.5703 / 1288284314653$

Teaching STEM. (2019). Retrieved October 28, 2019, from https://teach.com/careers/become-a-teacher/what-can-i-teach/stem/.

U.S. Department of Education(n.d.) Science, Technology, Engineering, and Math. Retrieved October 28, 2019, from https://www.ed.gov/stem.

Wyss, V. L., Heulskamp, D., \& Siebert, C. J. (2012). Increasing Middle School Student Interest in STEM Careers with Videos of Scientists. International Journal of Environmental and Science Educatio, 7, 501-522. 


\section{Appendix A: Instruments}

\section{Survey}

Attitudes towards STEM Survey

Directions:

There are lists of statements on the following pages. Please mark your answer sheets by marking how you feel about each statement. For example:

\begin{tabular}{|c|c|c|c|c|c|}
\hline Example 1: & $\begin{array}{c}\text { Strongly } \\
\text { Disagree }\end{array}$ & Disagree & $\begin{array}{c}\text { Neither } \\
\text { Agree nor } \\
\text { Disagree }\end{array}$ & Agree & $\begin{array}{c}\text { Strongly } \\
\text { Agree }\end{array}$ \\
\hline I like engineering. & 0 & 0 & 0 & 0 & 0 \\
\hline
\end{tabular}

As you read the sentence, you will know whether you agree or disagree. Fill in the circle that describes how much you agree or disagree.

There are no "right" or "wrong" answers! The only correct responses are those that are true for you. Whenever possible, let the things that have happened to you help you make a choice.

Please fill in on only one answer per question.

\begin{tabular}{|l|l|l|l|l|l|}
\hline Math & $\begin{array}{l}\text { Strongly } \\
\text { Disagree }\end{array}$ & Disagree & $\begin{array}{l}\text { Neither } \\
\text { Agree } \\
\text { nor } \\
\text { Disagree }\end{array}$ & Agree & $\begin{array}{l}\text { Strongly } \\
\text { Agree }\end{array}$ \\
\hline $\begin{array}{l}\text { Math has been my worst } \\
\text { subject. }\end{array}$ & & & & & \\
\hline $\begin{array}{l}\text { I would consider choosing a } \\
\text { career that uses math. }\end{array}$ & & & & & \\
\hline Math is hard for me. & & & & & \\
\hline $\begin{array}{l}\text { I am the type of student to do } \\
\text { well in math. }\end{array}$ & & & & & \\
\hline
\end{tabular}




\begin{tabular}{|l|l|l|l|l|l|}
\hline $\begin{array}{l}\text { I can handle most subjects } \\
\text { well, but I cannot do a good } \\
\text { job with math. }\end{array}$ & & & & & \\
\hline $\begin{array}{l}\text { I am sure I could do advanced } \\
\text { work in math. }\end{array}$ & & & & & \\
\hline I can get good grades in math. & & & & & \\
\hline I am good at math. & & & & & \\
\hline
\end{tabular}

\begin{tabular}{|l|l|l|l|l|l|}
\hline Science & $\begin{array}{l}\text { Strongly } \\
\text { Disagree }\end{array}$ & Disagree & $\begin{array}{l}\text { Neither } \\
\text { Agree } \\
\text { nor } \\
\text { Disagree }\end{array}$ & Agree & $\begin{array}{l}\text { Strongly } \\
\text { Agree }\end{array}$ \\
\hline $\begin{array}{l}\text { I am sure of myself when I do } \\
\text { science. }\end{array}$ & & & & \\
\hline $\begin{array}{l}\text { Science is hard for me. } \\
\text { I would consider a career in } \\
\text { science. }\end{array}$ & & & & & \\
\hline $\begin{array}{l}\text { I expect to use science when I } \\
\text { get out of school. }\end{array}$ & & & & & \\
\hline $\begin{array}{l}\text { Knowing science will help me } \\
\text { earn a living }\end{array}$ & & & & & \\
\hline $\begin{array}{l}\text { I will need science for my } \\
\text { future work. }\end{array}$ & & & & & \\
\hline $\begin{array}{l}\text { I know I can do well in } \\
\text { science. }\end{array}$ & & & & & \\
\hline $\begin{array}{l}\text { Science will be important to } \\
\text { me in my life's work. }\end{array}$ & & & & & \\
\hline job with science & & & & \\
\hline
\end{tabular}


I am sure I could do advanced work in science.

\begin{tabular}{|l|l|l|l|l|l|}
\hline Engineering/Technology & $\begin{array}{l}\text { Strongly } \\
\text { Disagree }\end{array}$ & Disagree & $\begin{array}{l}\text { Neither } \\
\text { Agree } \\
\text { nor } \\
\text { Disagree }\end{array}$ & Agree & $\begin{array}{l}\text { Strongly } \\
\text { Agree }\end{array}$ \\
\hline $\begin{array}{l}\text { I like to imagine creating new } \\
\text { products. }\end{array}$ & & & & \\
\hline $\begin{array}{l}\text { If I learn engineering, then I can } \\
\text { improve things that people use } \\
\text { every day }\end{array}$ & & & & & \\
\hline $\begin{array}{l}\text { I am good at building and fixing } \\
\text { things. }\end{array}$ & & & & & \\
\hline $\begin{array}{l}\text { I have no interest in } \\
\text { engineering. }\end{array}$ & & & & & \\
\hline $\begin{array}{l}\text { I am interested in what makes } \\
\text { machines work. }\end{array}$ & & & & & \\
\hline $\begin{array}{l}\text { Designing products or structures } \\
\text { will be important for my future } \\
\text { work. }\end{array}$ & & & & & \\
\hline $\begin{array}{l}\text { I am curious about how } \\
\text { electronics work. }\end{array}$ & & & & & \\
\hline $\begin{array}{l}\text { I would like to use creativity } \\
\text { and innovation in my future } \\
\text { work. }\end{array}$ & & & & & \\
\hline $\begin{array}{l}\text { Knowing how to use math and } \\
\text { science together will allow me } \\
\text { to invent useful things }\end{array}$ & & & & & \\
\hline $\begin{array}{l}\text { I believe I can be successful in } \\
\text { a career in engineering. }\end{array}$ & & & & & \\
\hline
\end{tabular}




\section{Directions:}

There are lists of STEM related careers on the following pages. Please mark your answer sheets by marking how you feel about each career.

\begin{tabular}{|c|c|c|c|c|}
\hline & $\begin{array}{l}\text { Not at all } \\
\text { Interested }\end{array}$ & $\begin{array}{l}\text { Not So } \\
\text { Interested }\end{array}$ & Interested & $\begin{array}{l}\text { Very } \\
\text { Interested }\end{array}$ \\
\hline $\begin{array}{l}\text { Physics: is the study motion, energy, } \\
\text { structure, and interactions of matter. } \\
\text { This can include studying the nature } \\
\text { of the universe. (aviation engineer, } \\
\text { alternative energy technician, lab } \\
\text { technician, physicist, astronomer) }\end{array}$ & & & & \\
\hline $\begin{array}{l}\text { Environmental Work: working to } \\
\text { improve the environment. This } \\
\text { includes finding and designing } \\
\text { solutions to problems like pollution, } \\
\text { reusing waste and recycling. }\end{array}$ & & & & \\
\hline $\begin{array}{l}\text { Biology and Zoology: involve the } \\
\text { study of living organisms. This } \\
\text { includes working with farm animals } \\
\text { and in areas like nutrition and } \\
\text { breeding. }\end{array}$ & & & & \\
\hline $\begin{array}{l}\text { Veterinary Work: involves the } \\
\text { science of preventing or treating } \\
\text { disease in animals. }\end{array}$ & & & & \\
\hline $\begin{array}{l}\text { Mathematics: involves computation, } \\
\text { algorithms and theory used to solve } \\
\text { problems and summarize data. } \\
\text { (accountant, applied mathematician, } \\
\text { economist, financial analyst, } \\
\text { mathematician, statistician, market } \\
\text { researcher, stock market analyst) }\end{array}$ & & & & \\
\hline $\begin{array}{l}\text { Medicine: involves maintaining } \\
\text { health and preventing and treating } \\
\text { disease. (physician's assistant, nurse, } \\
\text { doctor, nutritionist, emergency }\end{array}$ & & & & \\
\hline
\end{tabular}




\begin{tabular}{|l|l|l|l|}
\hline $\begin{array}{l}\text { medical technician, physical therapist, } \\
\text { dentist) }\end{array}$ & & & \\
\hline $\begin{array}{l}\text { Earth Science: is the study of earth, } \\
\text { including the air, land, and ocean. } \\
\text { (geologist, weather forecaster, } \\
\text { archaeologist, geoscientist) }\end{array}$ & & & \\
\hline $\begin{array}{l}\text { Computer Science: consists of the } \\
\text { development and testing of computer } \\
\text { systems, designing new programs and } \\
\text { helping others to use computers. }\end{array}$ & & & \\
\hline $\begin{array}{l}\text { Medical Science: involves } \\
\text { researching human disease and } \\
\text { working to find new solutions to } \\
\text { human health problems. }\end{array}$ & & & \\
\hline $\begin{array}{l}\text { Chemistry: uses math and } \\
\text { experiments to search for new } \\
\text { chemicals, and to study the structure } \\
\text { of matter and how it behaves. }\end{array}$ & & & \\
\hline $\begin{array}{l}\text { Energy: involves the study and } \\
\text { generation of power, such as heat or } \\
\text { electricity. }\end{array}$ & & & \\
\hline $\begin{array}{l}\text { Engineering: involves designing, } \\
\text { proding, and manufacturing new } \\
\text { science, and computers. }\end{array}$ & & & \\
\hline
\end{tabular}

As you read the sentence, you will know whether you agree or disagree. Fill in the circle that describes how much you agree or disagree.

\begin{tabular}{|l|l|l|l|l|l|}
\hline Online Learning & $\begin{array}{l}\text { Strongly } \\
\text { Disagree }\end{array}$ & Disagree & $\begin{array}{l}\text { Neither } \\
\text { Agree } \\
\text { nor } \\
\text { Disagree }\end{array}$ & Agree & $\begin{array}{l}\text { Strongly } \\
\text { Agree }\end{array}$ \\
\hline $\begin{array}{l}\text { I learn as well online as I do } \\
\text { in the classroom. }\end{array}$ & & & & \\
\hline
\end{tabular}




\begin{tabular}{|l|l|l|l|l|l|}
\hline $\begin{array}{l}\text { I find it easy to stay focused } \\
\text { with online learning. }\end{array}$ & & & & & \\
\hline $\begin{array}{l}\text { I need more interaction with } \\
\text { other students during my } \\
\text { online learning. }\end{array}$ & & & & & \\
\hline $\begin{array}{l}\text { I need more interaction with } \\
\text { the teacher with online } \\
\text { learning. }\end{array}$ & & & & & \\
\hline $\begin{array}{l}\text { I have all the materials } \\
\text { needed to make online } \\
\text { learning successful. }\end{array}$ & & & & & \\
\hline $\begin{array}{l}\text { I have good access to } \\
\text { internet for online learning. }\end{array}$ & & & & & \\
\hline
\end{tabular}

Survey adapted from: Friday Institute for Educational Innovation (2012). Upper Elementary School Student Attitudes toward STEM Survey. Raleigh, NC: Author.

\section{Rubric}

NGSS ENGINEERING PRACTICES RUBRIC STUDENT(S): DATE: 


\begin{tabular}{|l|l|l|l|l|l|}
\hline $\begin{array}{l}\text { Engineering } \\
\text { Practice } \\
\text { (NGSS) }\end{array}$ & \multicolumn{1}{|c|}{ Goals } & Poor & Progressing & \multicolumn{1}{|c|}{ Good } & Advanced \\
\hline $\begin{array}{l}\text { Defining } \\
\text { problems }\end{array}$ & $\begin{array}{l}\text { Define a problem that } \\
\text { can be solved through } \\
\text { the development of an } \\
\text { object, tool, process or } \\
\text { system and includes } \\
\text { multiple criteria and } \\
\text { constraints. }\end{array}$ & $\begin{array}{l}\text { Understood the } \\
\text { problem. }\end{array}$ & $\begin{array}{l}\text { Understood the } \\
\text { problem. Addressed } \\
\text { some of the } \\
\text { constraints of the } \\
\text { problem. }\end{array}$ & $\begin{array}{l}\text { Had a good } \\
\text { understanding of the } \\
\text { problem. Addressed } \\
\text { multiple criteria and } \\
\text { constraints. }\end{array}$ & $\begin{array}{l}\text { Had an exceptional } \\
\text { understanding of the } \\
\text { problem and could clearly } \\
\text { communicate it. } \\
\text { Addressed multiple } \\
\text { criteria and constraints } \\
\text { and understood the } \\
\text { relationships between } \\
\text { them. }\end{array}$ \\
\hline $\begin{array}{l}\text { Developing } \\
\text { and using } \\
\text { models }\end{array}$ & $\begin{array}{l}\text { Develop or modify a } \\
\text { model- based on } \\
\text { evidence } \text { to match } \\
\text { what happens if a } \\
\text { variable or component } \\
\text { of a system is } \\
\text { changed. }\end{array}$ & $\begin{array}{l}\text { Created a model of } \\
\text { the system but no } \\
\text { inputs or outputs are } \\
\text { listed. }\end{array}$ & $\begin{array}{l}\text { Created a model of } \\
\text { the system with one } \\
\text { input and one output. }\end{array}$ & $\begin{array}{l}\text { Created a model of the } \\
\text { system and can name } \\
\text { the all inputs and } \\
\text { outputs of the system. }\end{array}$ & $\begin{array}{l}\text { Created a model that } \\
\text { shows the relationships } \\
\text { between all of the inputs } \\
\text { and outputs in the system. }\end{array}$ \\
\hline $\begin{array}{l}\text { Planning and } \\
\text { carrying out } \\
\text { investigations }\end{array}$ & $\begin{array}{l}\text { Collect data about the } \\
\text { performance of a } \\
\text { proposed object, tool, } \\
\text { process or system } \\
\text { under a range of } \\
\text { conditions. Evaluate } \\
\text { the accuracy of } \\
\text { various methods for } \\
\text { collecting data. }\end{array}$ & $\begin{array}{l}\begin{array}{l}\text { Collected insufficient } \\
\text { data }\end{array} \\
\text { Collected data }\end{array}$ & $\begin{array}{l}\text { Collected data and } \\
\text { evaluated the accuracy } \\
\text { of our data collection } \\
\text { method. }\end{array}$ & $\begin{array}{l}\text { Collected significant } \\
\text { amounts of data and } \\
\text { improved the accuracy of } \\
\text { our data collection } \\
\text { methods }\end{array}$ \\
\hline
\end{tabular}




\begin{tabular}{|c|c|c|c|c|c|}
\hline $\begin{array}{l}\text { Analyzing } \\
\text { and } \\
\text { interpreting } \\
\text { data }\end{array}$ & $\begin{array}{l}\text { Analyze data by } \\
\text { looking for trends. } \\
\text { Consider limitations } \\
\text { of data analysis (e.g., } \\
\text { measurement error), } \\
\text { and/or seek to } \\
\text { improve accuracy of } \\
\text { data. }\end{array}$ & No data analysis & $\begin{array}{l}\text { Analyzed the data of } \\
\text { the single trial. }\end{array}$ & $\begin{array}{l}\text { Analyzed the data from } \\
\text { multiple trials. Also } \\
\text { considered the } \\
\text { limitations of data } \\
\text { collection and analysis. }\end{array}$ & $\begin{array}{l}\text { Analyzed data using } \\
\text { multiple trials and created } \\
\text { and/or used different tools } \\
\text { to improve accuracy of } \\
\text { the data. Also considered } \\
\text { the limitations of data } \\
\text { collection and analysis. }\end{array}$ \\
\hline $\begin{array}{l}\text { Using } \\
\text { mathematics } \\
\text { and } \\
\text { computationa } \\
1 \text { thinking }\end{array}$ & $\begin{array}{l}\text { Use mathematical } \\
\text { concepts and } \\
\text { arguments to test and } \\
\text { compare proposed } \\
\text { solutions to an } \\
\text { engineering design } \\
\text { problem. Apply } \\
\text { mathematical } \\
\text { concepts and create } \\
\text { algorithms to solve a } \\
\text { problem. }\end{array}$ & $\begin{array}{l}\text { Found a solution to } \\
\text { the design problem } \\
\text { using trial and error. }\end{array}$ & $\begin{array}{l}\text { Used some } \\
\text { mathematical } \\
\text { arguments to test and } \\
\text { compare proposed } \\
\text { solution. }\end{array}$ & $\begin{array}{l}\text { Used mathematical } \\
\text { concepts and arguments } \\
\text { to test and compare } \\
\text { proposed solutions. } \\
\text { Created algorithms to } \\
\text { solve the problem. }\end{array}$ & $\begin{array}{l}\text { Used mathematical } \\
\text { concepts and arguments to } \\
\text { test and compare } \\
\text { proposed solutions. } \\
\text { Created efficient } \\
\text { algorithms to solve the } \\
\text { problem. }\end{array}$ \\
\hline $\begin{array}{l}\text { Designing } \\
\text { solutions }\end{array}$ & $\begin{array}{l}\text { Undertake a design } \\
\text { project, engaging in } \\
\text { the design cycle, to } \\
\text { construct and/or } \\
\text { implement a solution } \\
\text { that meets specific } \\
\text { design criteria and } \\
\text { constraints. Optimize } \\
\text { performance of a } \\
\text { design by prioritizing } \\
\text { criteria, making } \\
\text { tradeoffs, testing, } \\
\text { revising, and re- } \\
\text { testing. Apply } \\
\text { scientific ideas or }\end{array}$ & $\begin{array}{l}\text { Completed a design } \\
\text { project, engaging in } \\
\text { the design cycle, to } \\
\text { construct and } \\
\text { implement a solution. }\end{array}$ & $\begin{array}{l}\text { Completed a design } \\
\text { project, engaging in } \\
\text { the design cycle, to } \\
\text { construct and } \\
\text { implement a solution } \\
\text { that met specific } \\
\text { design criteria and } \\
\text { constraints. Applied } \\
\text { some scientific ideas } \\
\text { or principles to } \\
\text { design, construct, } \\
\text { and/or test a design of } \\
\text { an object, tool, } \\
\text { process or system. }\end{array}$ & $\begin{array}{l}\text { Completed a design } \\
\text { project, engaging in the } \\
\text { design cycle, to } \\
\text { construct and implement } \\
\text { a solution that met } \\
\text { specific design criteria } \\
\text { and constraints. } \\
\text { Optimized performance } \\
\text { of a design by using } \\
\text { some of the following: } \\
\text { prioritizing criteria, } \\
\text { making tradeoffs, } \\
\text { testing, revising, and re- } \\
\text { testing. Applied } \\
\text { scientific ideas or }\end{array}$ & $\begin{array}{l}\text { Creatively used the } \\
\text { engineering design } \\
\text { process to implement a } \\
\text { solution that met specific } \\
\text { design criteria and } \\
\text { constraints. Optimized } \\
\text { performance of a design } \\
\text { by using of the following: } \\
\text { prioritizing criteria, } \\
\text { making tradeoffs, testing, } \\
\text { revising, and re- testing. } \\
\text { Applied and could clearly } \\
\text { articulate many a } \\
\text { scientific ideas or } \\
\text { principles to design, }\end{array}$ \\
\hline
\end{tabular}




\begin{tabular}{|c|c|c|c|c|c|}
\hline & $\begin{array}{l}\text { principles to design, } \\
\text { construct, and/or test a } \\
\text { design of an object, } \\
\text { tool, process or } \\
\text { system. }\end{array}$ & & & $\begin{array}{l}\text { principles to design, } \\
\text { construct, and/or test a } \\
\text { design of an object, tool, } \\
\text { process or system. }\end{array}$ & $\begin{array}{l}\text { construct, and/or test a } \\
\text { design of an object, tool, } \\
\text { process or system. }\end{array}$ \\
\hline $\begin{array}{l}\text { Engaging in } \\
\text { argument } \\
\text { from } \\
\text { evidence }\end{array}$ & $\begin{array}{l}\text { Evaluate competing } \\
\text { design solutions based } \\
\text { on jointly developed } \\
\text { and agreed-upon } \\
\text { design criteria. }\end{array}$ & $\begin{array}{l}\text { Considered one } \\
\text { design idea. }\end{array}$ & $\begin{array}{l}\text { Evaluated at least } 2 \\
\text { different competing } \\
\text { design solutions. }\end{array}$ & $\begin{array}{l}\text { Evaluated more than } 2 \\
\text { competing design } \\
\text { solutions based on } \\
\text { design criteria. }\end{array}$ & $\begin{array}{l}\text { Evaluated more than } 3 \\
\text { competing design } \\
\text { solutions based on design } \\
\text { criteria. }\end{array}$ \\
\hline $\begin{array}{l}\text { Obtaining, } \\
\text { evaluating, } \\
\text { and } \\
\text { communicati } \\
\text { ng } \\
\text { information }\end{array}$ & $\begin{array}{l}\text { Communicate } \\
\text { scientific and/or } \\
\text { technical information } \\
\text { (e.g. about a proposed } \\
\text { object, tool, process, } \\
\text { system) in writing } \\
\text { and/or through oral } \\
\text { presentations. }\end{array}$ & $\begin{array}{l}\text { Described the } \\
\text { solution in writing or } \\
\text { through oral } \\
\text { presentations. }\end{array}$ & $\begin{array}{l}\text { Described the } \\
\text { solution using } \\
\text { scientific information } \\
\text { in writing or through } \\
\text { oral presentations. }\end{array}$ & $\begin{array}{l}\text { Described solution } \\
\text { using clear and } \\
\text { accurate scientific } \\
\text { information in writing } \\
\text { or through oral } \\
\text { presentations. }\end{array}$ & $\begin{array}{l}\text { Creatively described } \\
\text { solution using clear and } \\
\text { accurate scientific } \\
\text { information in writing or } \\
\text { through oral } \\
\text { presentations. }\end{array}$ \\
\hline
\end{tabular}


Adapted from: NGSS Engineering Practices Rubric Student. (2011, August). Retrieved November 17, 2019, from https://kidsengineer.com/wp-content/uploads/2011/08/NGSSEngineering-Practices-Rubric-Student-.docx. 


\section{Appendix B: Supplementary Data Tables}

Table 15: Descriptive Statistics Rubric Scores

\begin{tabular}{|c|c|c|c|c|c|c|c|c|}
\hline & \multicolumn{2}{|c|}{$\begin{array}{c}\text { Rubric- Defining } \\
\text { problems }\end{array}$} & \multicolumn{2}{|c|}{$\begin{array}{l}\text { Rubric-Developing } \\
\text { and using models }\end{array}$} & \multicolumn{2}{|c|}{$\begin{array}{l}\text { Rubric-Planning and } \\
\text { carrying out investigations }\end{array}$} & \multicolumn{2}{|c|}{$\begin{array}{l}\text { Rubric-Analyzing and } \\
\text { interpreting data }\end{array}$} \\
\hline & 1 & 2 & 1 & 2 & 1 & 2 & 1 & 2 \\
\hline Valid & 27 & 24 & 27 & 24 & 27 & 24 & 27 & 24 \\
\hline Missing & 0 & 0 & 0 & 0 & 0 & 0 & 0 & 0 \\
\hline Mean & 3.593 & 3.375 & 3.185 & 3.250 & 3.111 & 3.125 & 2.444 & 3.125 \\
\hline $\begin{array}{l}\text { Std. } \\
\text { Deviation }\end{array}$ & 0.971 & 0.875 & 1.111 & 0.847 & 1.086 & 1.076 & 0.751 & 0.797 \\
\hline
\end{tabular}

$\begin{array}{ccc}\text { Rubric-Using } & \text { Rubric- } & \text { Rubric-Engaging in } \\ \text { mathematics and } & \begin{array}{c}\text { Designing } \\ \text { solutions }\end{array} & \begin{array}{c}\text { evidence } \\ \text { computational thinking }\end{array}\end{array}$

Rubric-Obtaining, evaluating, and communicating information

1 2 1 2 1 2 1

\begin{tabular}{lrrrrrrrr} 
& $\mathbf{1}$ & $\mathbf{2}$ & $\mathbf{1}$ & $\mathbf{2}$ & $\mathbf{1}$ & $\mathbf{2}$ & $\mathbf{1}$ & $\mathbf{2}$ \\
\hline Valid & 27 & 24 & 27 & 24 & 27 & 24 & 27 & 24 \\
Missing & 0 & 0 & 0 & 0 & 0 & 0 & 0 & 0 \\
Mean & 2.259 & 2.500 & 2.852 & 2.500 & 2.852 & 3.250 & 3.704 & 3.750 \\
$\begin{array}{l}\text { Std. } \\
\text { Deviation }\end{array}$ & 0.656 & 1.022 & 0.818 & 1.022 & 0.818 & 0.847 & 0.669 & 0.442 \\
\hline
\end{tabular}




\section{Table 16: Independent Samples T-Test Rubric Scores}

\begin{tabular}{lrl}
\hline & $\mathbf{t} \mathbf{d f} \quad \mathbf{p}$ \\
\hline Rubric- Defining problems & 0.836490 .407 \\
Rubric-Developing and using models & -0.232490 .817 \\
Rubric-Planning and carrying out investigations & -0.046490 .964 \\
Rubric-Analyzing and interpreting data & -3.138490 .003 \\
Rubric-Using mathematics and computational thinking & $-1.013490 .316^{\mathrm{a}}$ \\
Rubric-Designing solutions & $1.364490 .179^{\mathrm{a}}$ \\
Rubric-Engaging in argument from evidence & -1.706490 .094 \\
Rubric-Obtaining, evaluating, and communicating information & -0.288490 .775 \\
\hline
\end{tabular}


Table 17: Descriptive Statistics Rubrics Males vs Females

\begin{tabular}{|c|c|c|c|c|c|c|c|c|}
\hline & \multicolumn{2}{|c|}{$\begin{array}{l}\text { Rubric- } \\
\text { Defining } \\
\text { problems }\end{array}$} & \multicolumn{2}{|c|}{$\begin{array}{c}\text { Rubric- } \\
\text { Developing and } \\
\text { using models }\end{array}$} & \multicolumn{2}{|c|}{$\begin{array}{l}\text { Rubric-Planning } \\
\text { and carrying out } \\
\text { investigations }\end{array}$} & \multicolumn{2}{|c|}{$\begin{array}{c}\text { Rubric- } \\
\text { Analyzing and } \\
\text { interpreting } \\
\text { data }\end{array}$} \\
\hline & Female & Male & Female & Male & Female & Male & Female & Male \\
\hline Valid & 27 & 24 & 27 & 24 & 27 & 24 & 27 & 24 \\
\hline Missing & 0 & 0 & 0 & 0 & 0 & 0 & 0 & 0 \\
\hline Mean & 3.630 & 3.333 & 3.481 & 2.917 & 3.296 & 2.917 & 2.926 & 2.583 \\
\hline $\begin{array}{l}\text { Std. } \\
\text { Deviation }\end{array}$ & 0.792 & 1.049 & 0.802 & 1.100 & 1.031 & 1.100 & 0.730 & 0.929 \\
\hline Minimum & 2.000 & 1.000 & 2.000 & 1.000 & 1.000 & 1.000 & 2.000 & 1.000 \\
\hline Maximum & 4.000 & 4.000 & 4.000 & 4.000 & 4.000 & 4.000 & 4.000 & 4.000 \\
\hline
\end{tabular}

\begin{tabular}{|c|c|c|c|c|c|c|c|c|}
\hline & \multicolumn{2}{|c|}{$\begin{array}{l}\text { Rubric-Using } \\
\text { mathematics } \\
\text { and } \\
\text { computational } \\
\text { thinking }\end{array}$} & \multicolumn{2}{|c|}{$\begin{array}{l}\text { Rubric- } \\
\text { Designing } \\
\text { solutions }\end{array}$} & \multicolumn{2}{|c|}{$\begin{array}{c}\text { Rubric- } \\
\text { Engaging in } \\
\text { argument } \\
\text { from evidence }\end{array}$} & \multicolumn{2}{|c|}{$\begin{array}{c}\text { Rubric- } \\
\text { Obtaining, } \\
\text { evaluating, and } \\
\text { communicating } \\
\text { information }\end{array}$} \\
\hline & Female & Male & Female & Male & Female & Male & Female & Male \\
\hline Valid & 27 & 24 & 27 & 24 & 27 & 24 & 27 & 24 \\
\hline Missing & 0 & 0 & 0 & 0 & 0 & 0 & 0 & 0 \\
\hline Mean & 2.407 & 2.333 & 2.778 & 2.583 & 3.111 & 2.958 & 3.815 & 3.625 \\
\hline $\begin{array}{l}\text { Std. } \\
\text { Deviation }\end{array}$ & 0.888 & 0.816 & 0.974 & 0.881 & 0.698 & 0.999 & 0.396 & 0.711 \\
\hline Minimum & 1.000 & 1.000 & 1.000 & 1.000 & 2.000 & 1.000 & 3.000 & 2.000 \\
\hline Maximum & 4.000 & 4.000 & 4.000 & 4.000 & 4.000 & 4.000 & 4.000 & 4.000 \\
\hline
\end{tabular}


Table 18: Independent Samples T-Test Rubric Males vs. Females

\begin{tabular}{llll} 
& $\mathbf{t}$ & $\mathbf{d f}$ & $\mathbf{p}$ \\
\hline Rubric- Defining problems & 1.146 & 49 & 0.257 \\
Rubric-Developing and using models & 2.111 & 49 & 0.040 \\
Rubric-Planning and carrying out investigations & 1.272 & 49 & 0.209 \\
Rubric-Analyzing and interpreting data & 1.473 & 49 & 0.147 \\
Rubric-Using mathematics and computational thinking & 0.309 & 49 & 0.759 \\
Rubric-Designing solutions & 0.744 & 49 & 0.460 \\
Rubric-Engaging in argument from evidence & 0.639 & 49 & 0.526 \\
Rubric-Obtaining, evaluating, and communicating information & 1.195 & 49 & $0.238^{\mathrm{a}}$ \\
\hline
\end{tabular}

Note. Student's t-test.

${ }^{a}$ Levene's test is significant $(\mathrm{p}<.05)$, suggesting a violation of the equal variance assumption 


\section{Appendix C: Project Descriptions}

\section{Cardboard Boat Project}

Objectives:

1. Students will complete a design process on building a cardboard boat.

2. Students will Students will construct cardboard boat.

3. Students will race their boat at our school pool ( 2 teammates must be in the boat during race.

Guidelines:

1. Maximum boat size $==8$ feet long $X 30$ inched wide $X 30$ inches tall.

2. Cardboard only (not wax coated).

3. No flotation assistance allowed.

4. 3 rolls of duct tape provided.

7. Students must wear life jackets while in the water (furnished by instructor).

8. Instructor reserves the right to critique the boat to determine if the boat will be allowed to compete in the race. Decision is based on cosmetic appearance, construction, durability and safety.

\section{Miniature Crime Scene Project}

Objectives:

1. Students will complete the design process on sketching a murder scene.

2. Students will construct a diorama of the crime scene.

3. Students will present their diorama and convince the class the suspect is guilty based on evidence.

Crime Scene Project:

1. Give your crime scene a title.

2. Write a description of your crime scene.

3. Sketch the crime scene. Sketch must include measurements, scale factor and label all evidence.

4. Complete an autopsy report for the victim.

5. Create a diorama using a cardboard box.

6. Give a presentation using Google Slides describing the crime scene and convincing the "jury" that the suspect you identified is guilty. 


\section{Appendix D: Project Pictures}
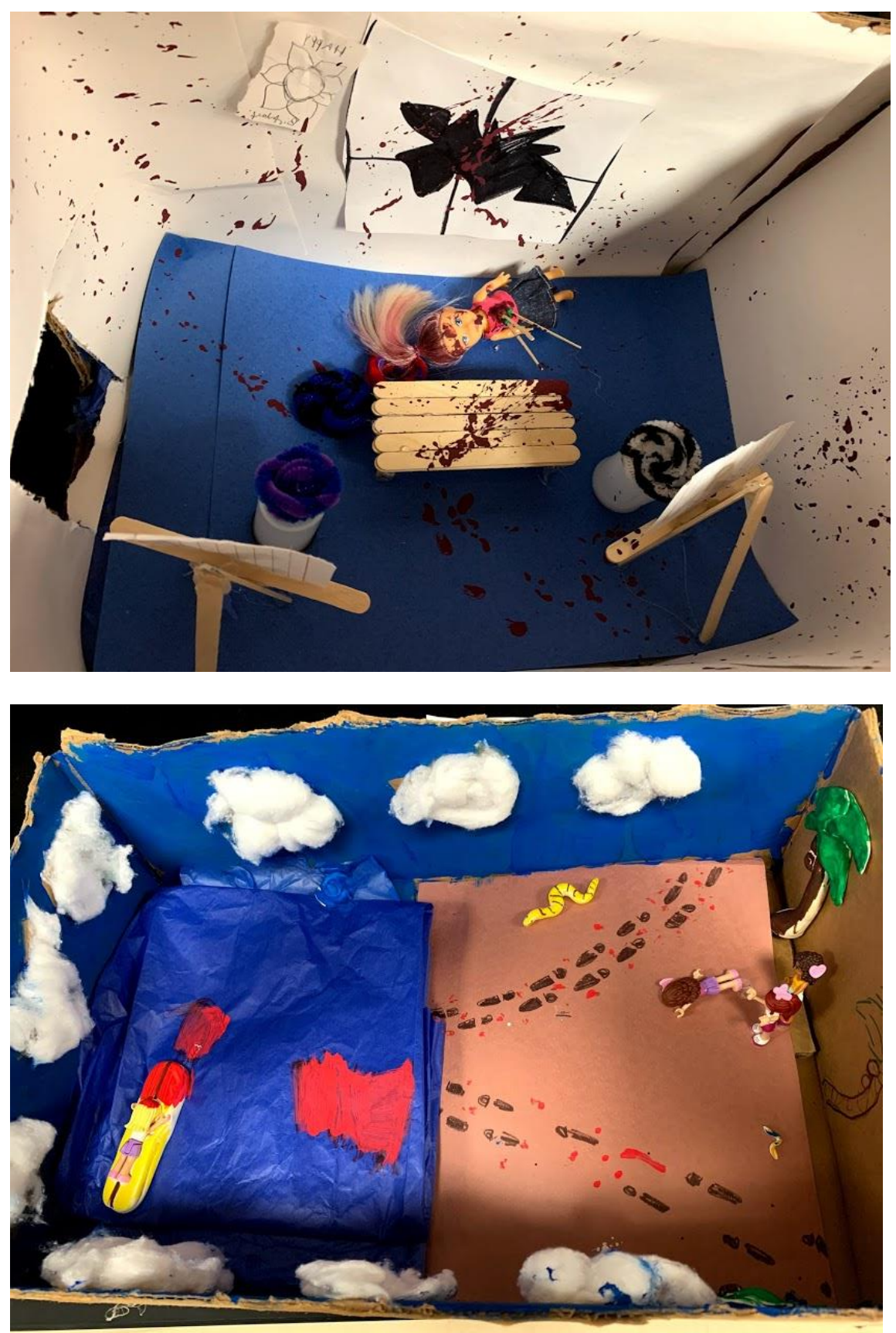

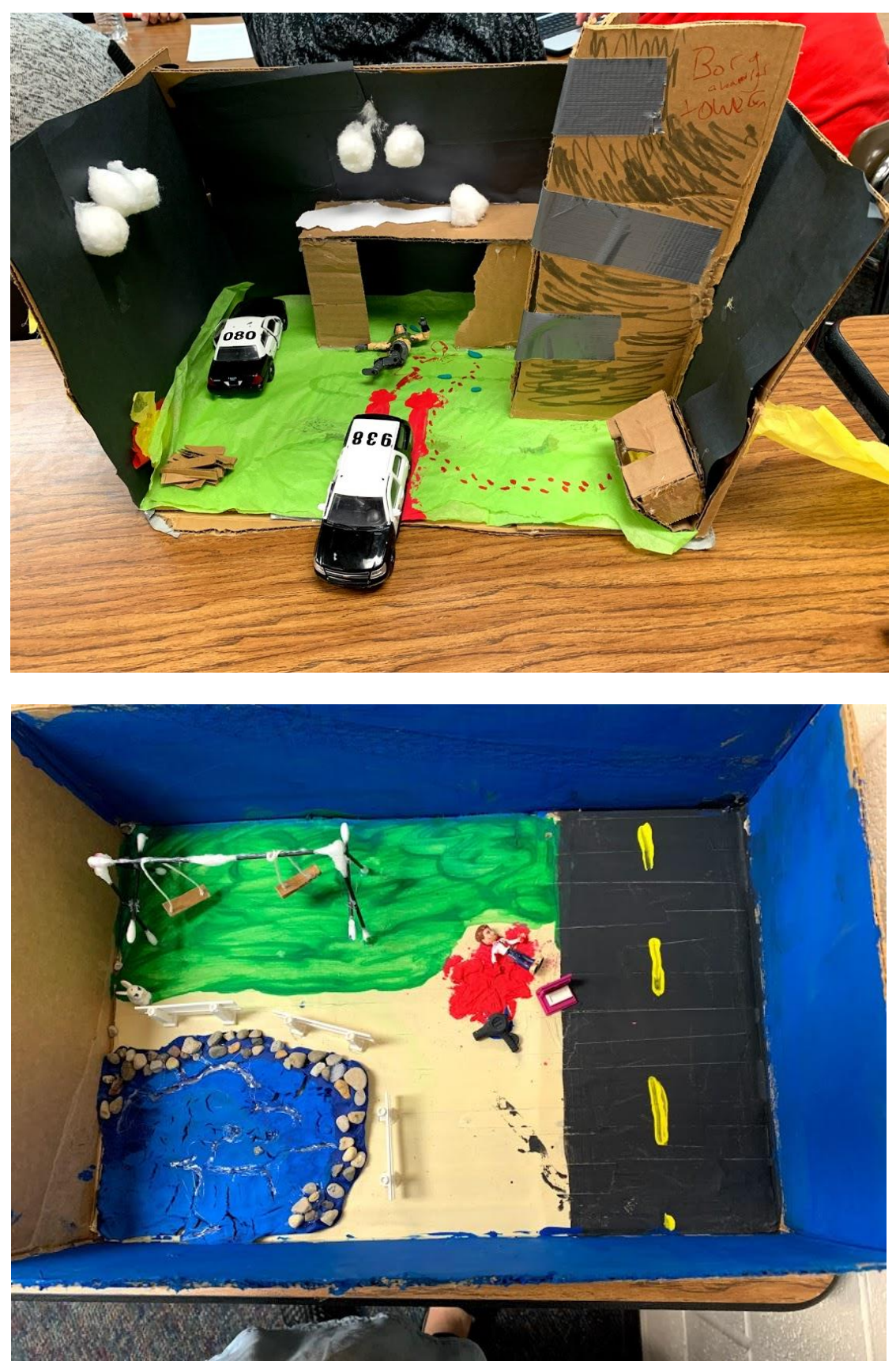

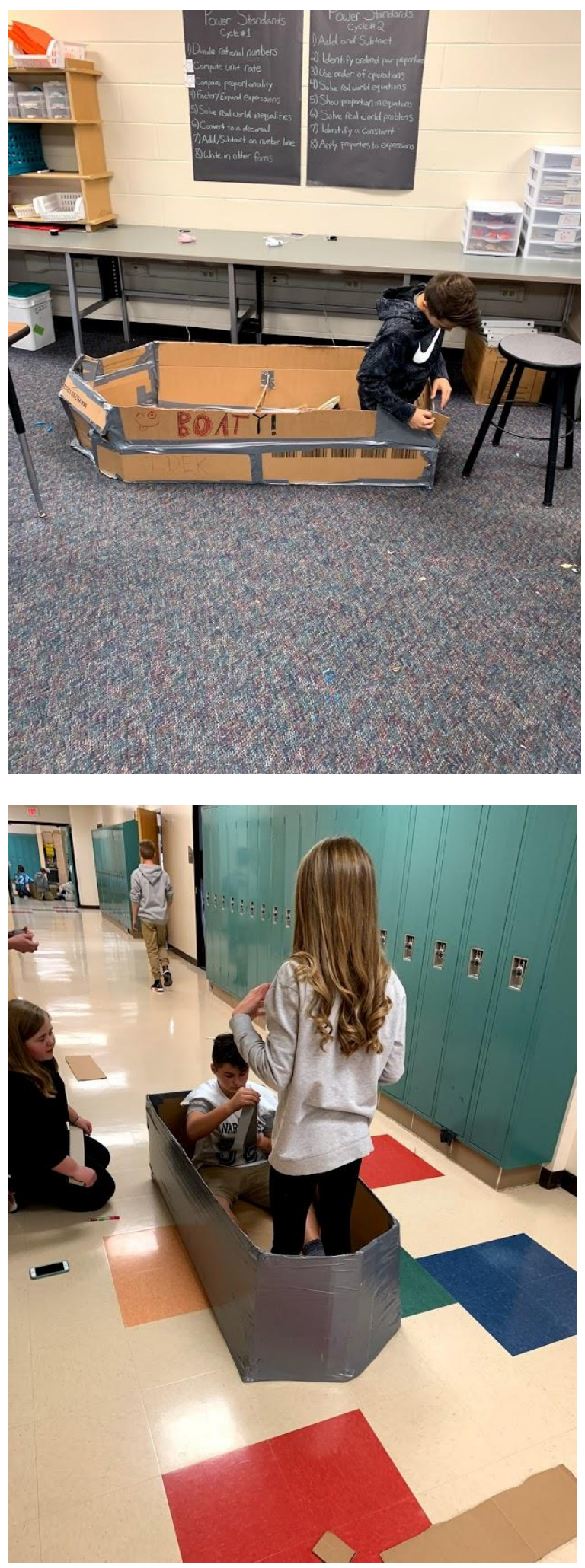

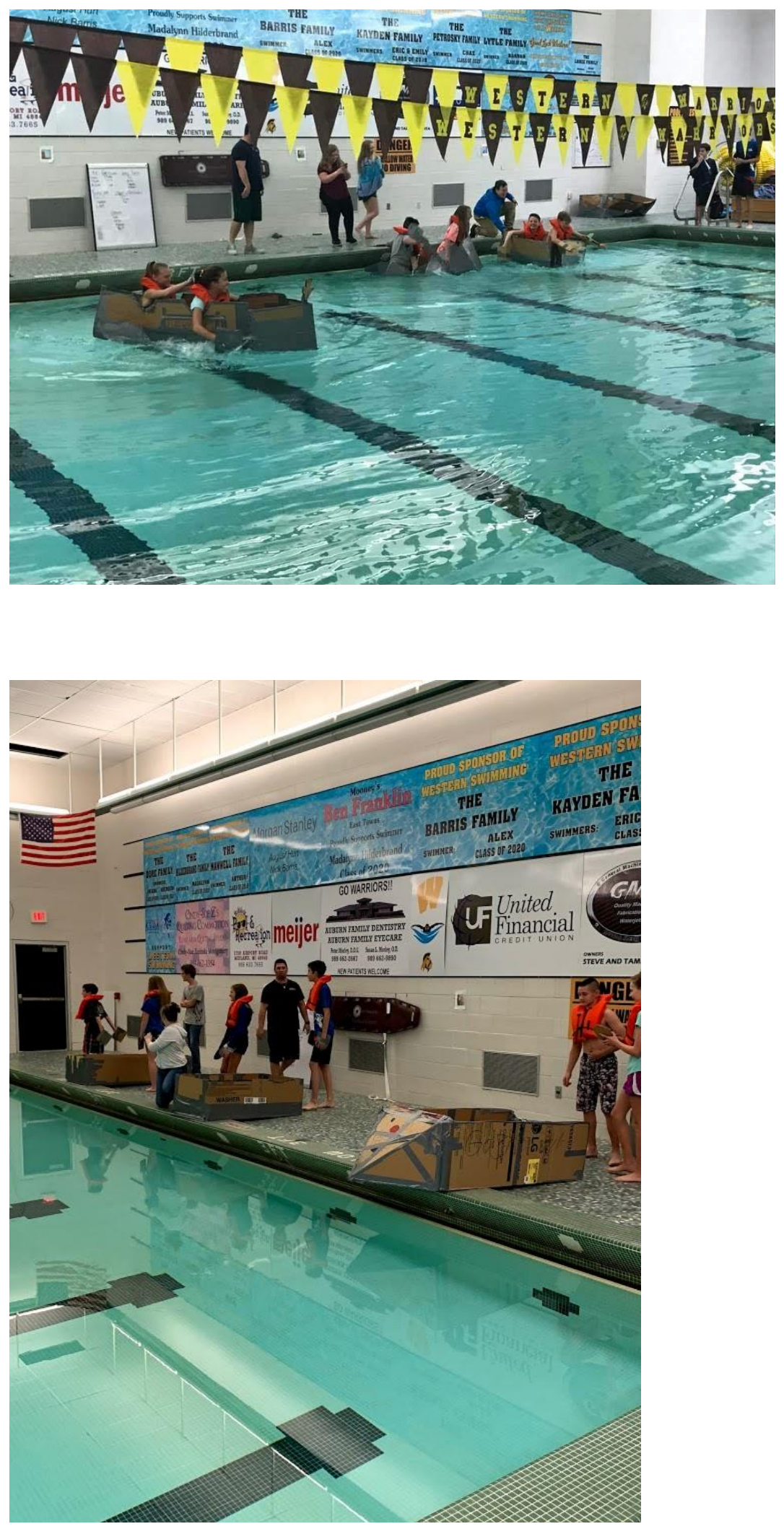